\title{
Features of pragmatism in Arabic texts: Maqamat Al-Zamakhshari as a
}

\section{Case study}

Nurul Hanilah Binti Mohd Ismath hanilah@iium.edu.my

Assistant professor, College of Languages and Management, International Islamic University Malaysia. (Corresponding Author)

Abdul Hadi Bin Abd Aziz abdulhadi@uthm.edu.my
Centre of Language Studies, University Tun Hussein Onn Malaysia

Nor Zainiyah Norita Mokhtar mnzainiyah@iium.edu.my

College of Languages and Management, International Islamic University Malaysia

Arina Binti Johari arinajr@iium.edu.my

College of Languages and Management, International Islamic University Malaysia

\begin{abstract}
Since the graphic images of an analogy, metaphor, metaphor, and metaphor, seek to influence the recipient and enable meaning in his mind, it can be said that they are of deliberative dimensions. This research has investigated the maqamat of al-Zamakhshari with a descriptive-analytical method, in order to reveal the features of deliberation, represented by the means of harmony in the science of rhetoric through the process of thinking and interpretation. In other words, the research deals with the Arab linguistic heritage and attempts to relate it to the data of Western theory in accordance with the concept of text's syntax in proportion to it with the maqamat of Zamakhshari. What is noticed in these maqamas is that textual coherence is clearly evidenced. Al-Zamakhshari has employed the means of harmony well, weaving its maqamat coherently, and the text of the text was realized with the emergence of these means. In the analysis of the maqamat, the importance of the recipient's role in analyzing the text and deciphering its elements was highlighted by his perception of the language of the text and its context. The study demonstrated the close relationship between Arab heritage and the text's syntax, and this is what we have seen from the contribution of the science of rhetoric after it, one of the means of text harmony.
\end{abstract}

key words: Studes in Arabic narratology, Text grammar, textual coherence, Pragmatics, 'Ilm Al Bayan, Maqamat Al-Zamakhshari

Citation: Ismath, N; Bin Abdul Aziz, A; Norita Mokhtar, N; Johari, A. Autumn \& Winter (2020-2021). Features of pragmatism in Arabic texts: Maqamat Al-Zamakhshari as a Case study. Studies in Arabic Narratology, 2(3), 1-29. (In Arabic) 
Studies in Arabic Narratology, Autumn \& Winter (2020-2021), Vol. 2, No.3, pp. 1-29

Received: September 27, 2020; $\quad$ Accepted: Desember25, 2020

CFaculty of Literature \& Humanities, University of Kharazmi and Iranian Association of Arabic Language \& Literature. 

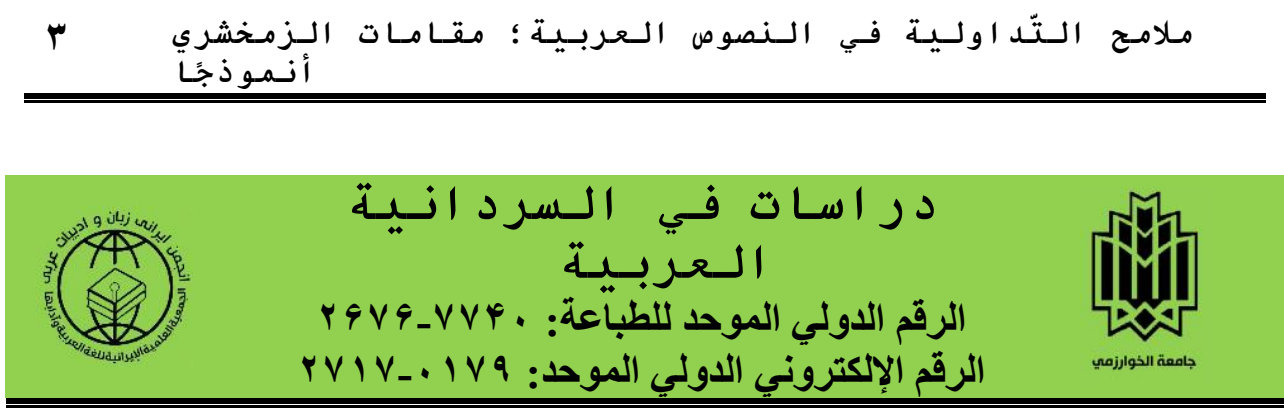

$$
\text { فور الحنيلة بنت محمد اسماث }
$$

أستاذة كلية اللغات و الإدارة ، الجامعة الإسلامية العالمية ،ماليزيا(الكاتبة المسؤولة). abdulhadi@uthm.edu.my

البريد البية

عبد الهادي بن عبد العزيز

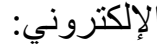

مركز در اسات اللغة ، جامعة تون حسين أون ،ماليزيا.

mnzainiyah@iiu.edu.my

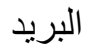

نور زينية نوريتا مختار

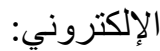

arinajr@iium.edu.my

كلية اللغات و الإدارة ، الجامعة الإسلامية العالمية ،ماليزيا.

$$
\text { كلية اللغات والإدارة ، الجامعة الإسلامية العالمية ،ماليزيا }
$$

الإحالة: عصمت، نور الحنيلة بنت محمد؛ عبدالهادي بن عبدالعزيز؛

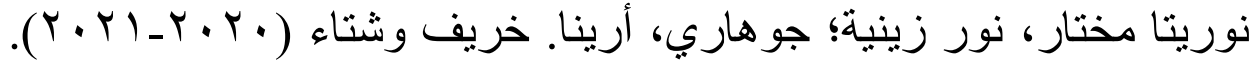
ملامح التّاولية في النصوص التّار العربية؛ مقامات الزمخشري أنموذجًا. در اسات

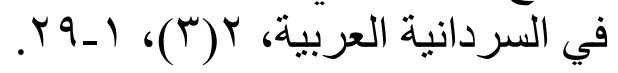

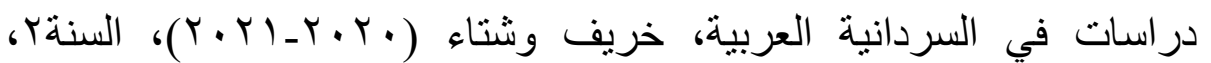

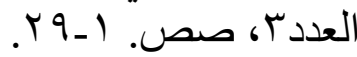

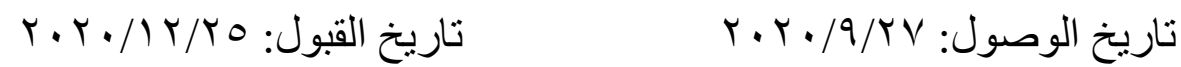

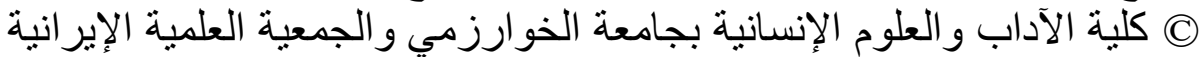

للغة العربية و آدابها. 


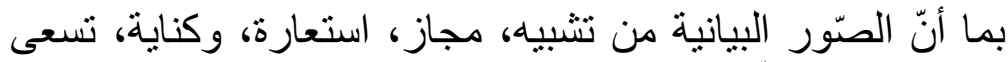

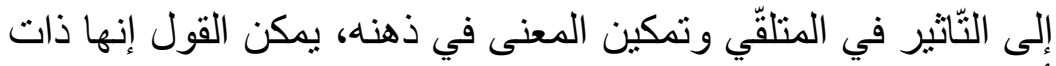

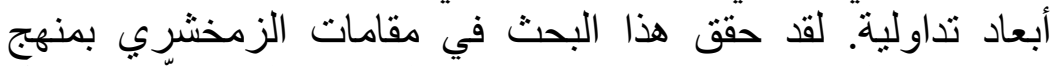
وصفي -تحليلي كى يكثف عن ملامح التداولية التي تمثّلت وسائل

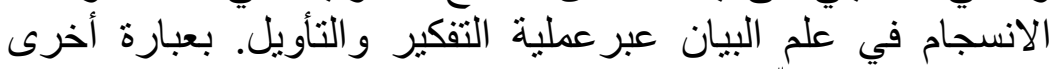

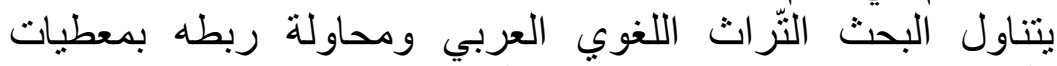

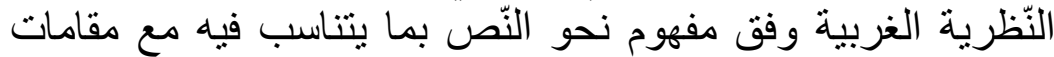

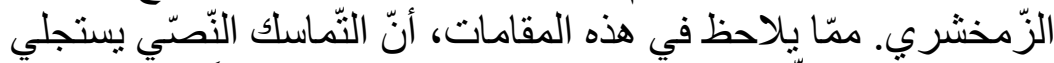

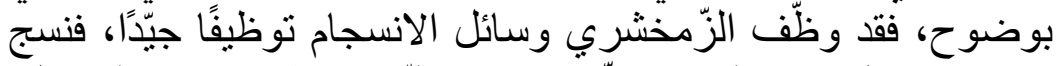

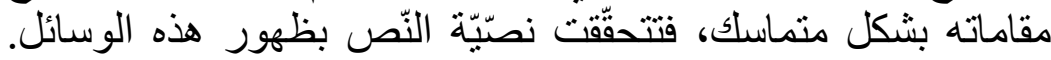

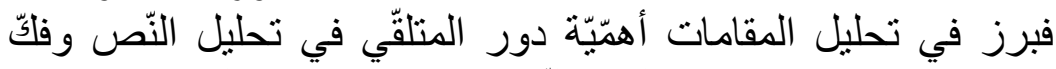

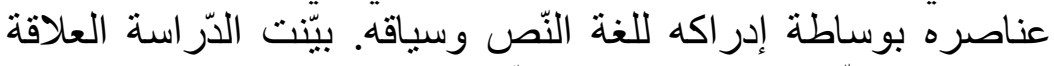
الوثيقة بين التّراث العربي ونحو النّص، ورها هذا ما لمسناه من مساهمة علم البيان بعدّة وسيلة من وسائل انسجام النّص.

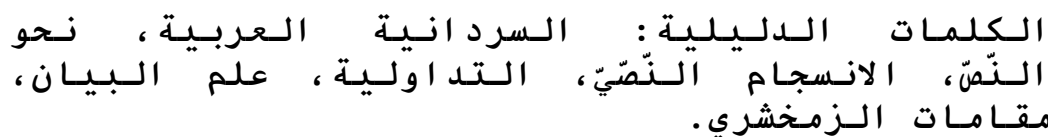




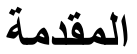

يتطلَّع و يستهدف هذا البحث إلى استجلاء عناصر التّداولية في التراث

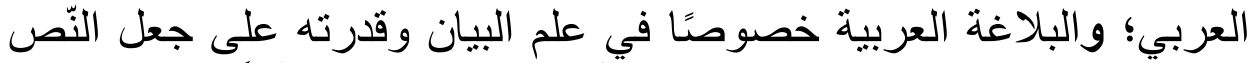

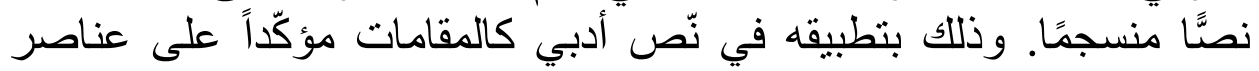

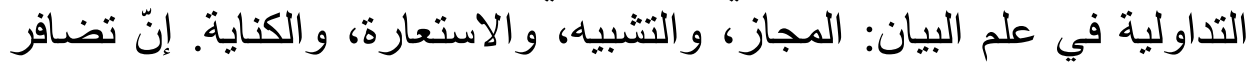

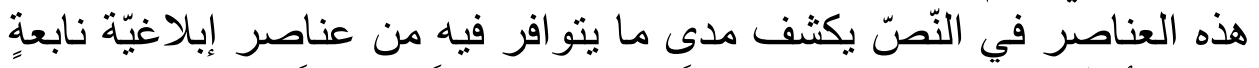

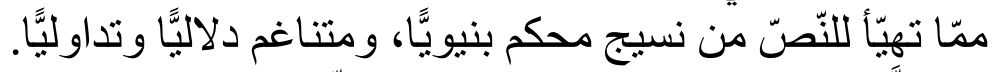

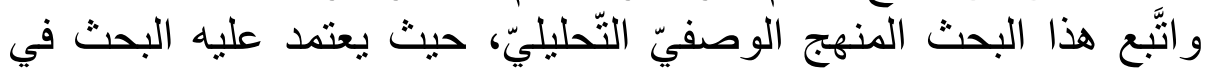

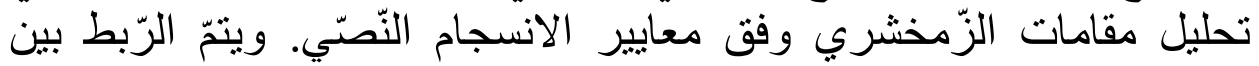

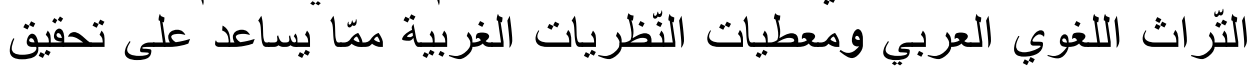

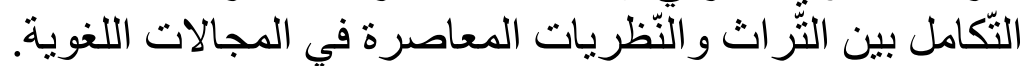

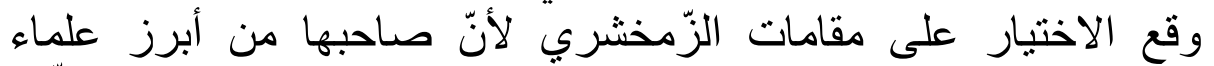

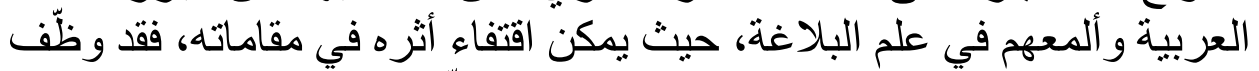

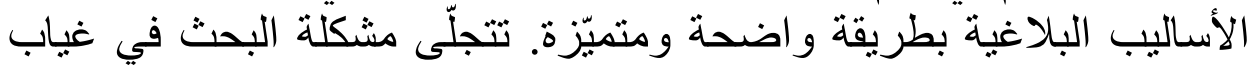

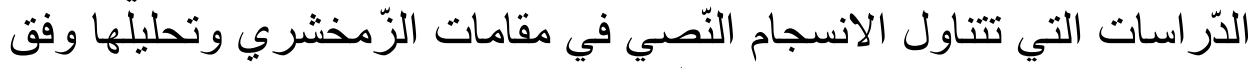

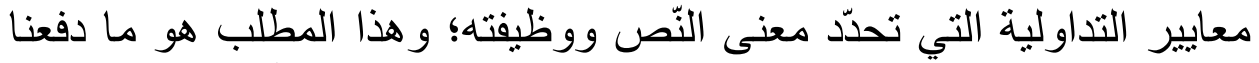

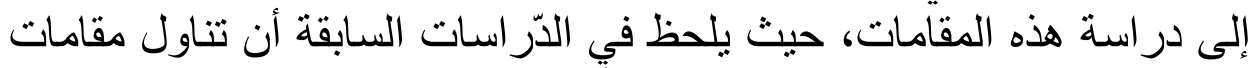

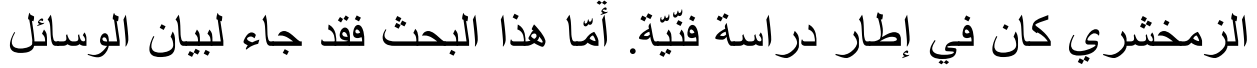

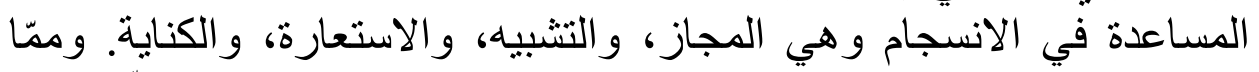

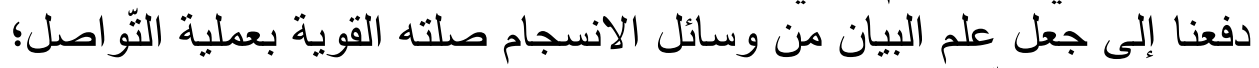

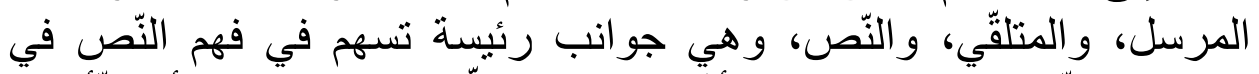

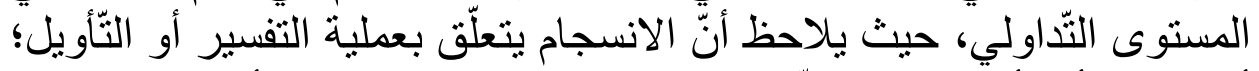

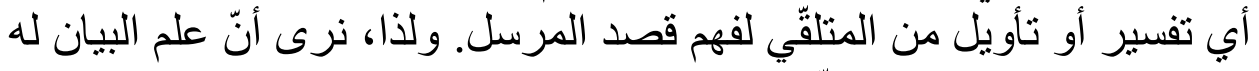

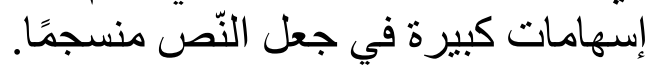

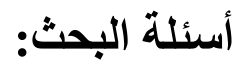
تحاول هذه المقالة الإجابة على هذه الأسئلة:

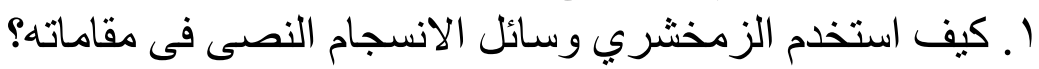

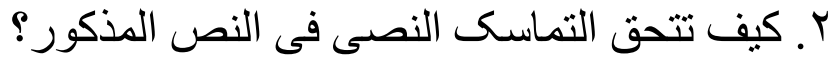


التّّاولية لها مساهمة كبيرة في تحليل النّص لكونها ترتبط ارتباطًا قويّاً

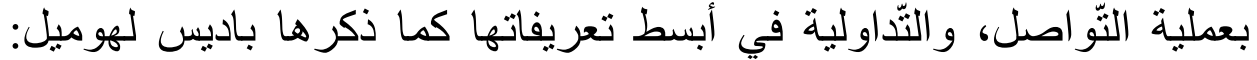

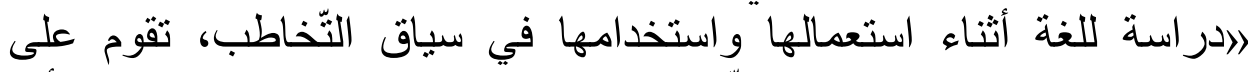

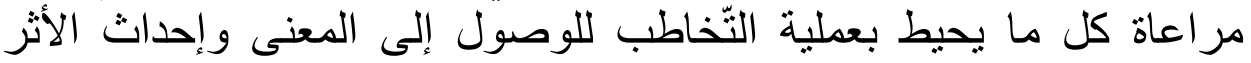

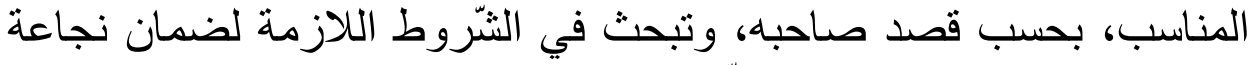

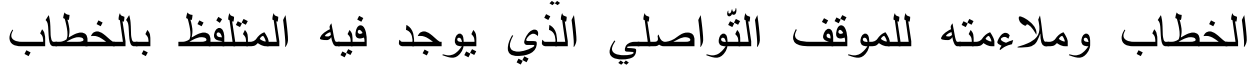

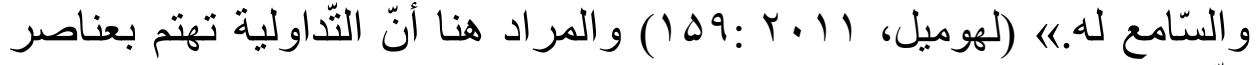

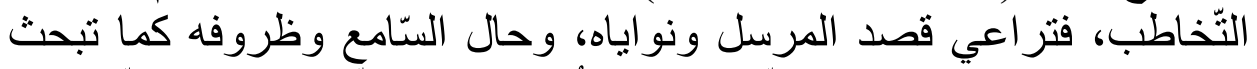

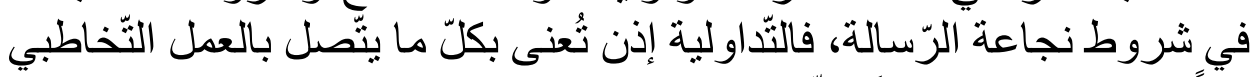

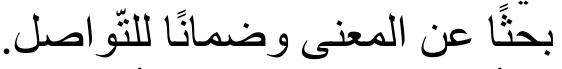

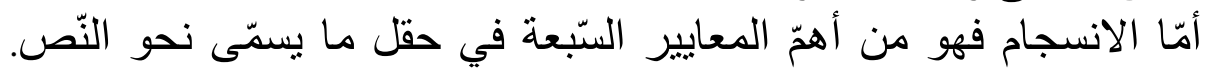

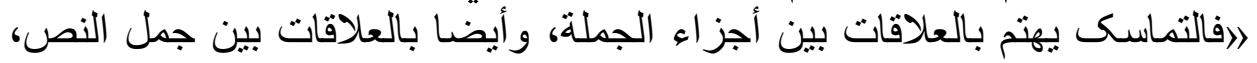

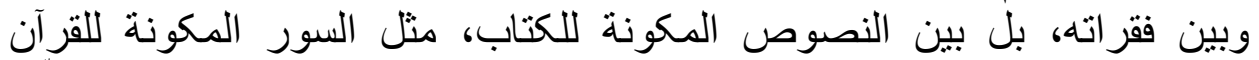

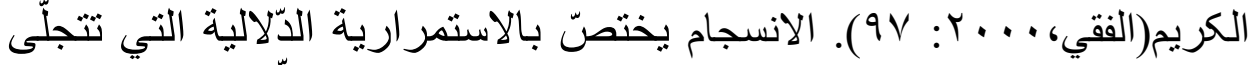

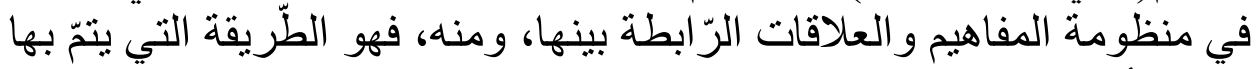

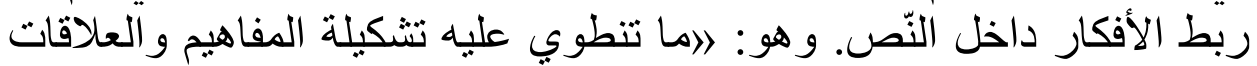

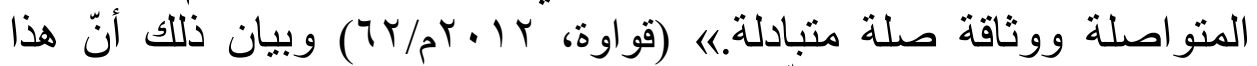

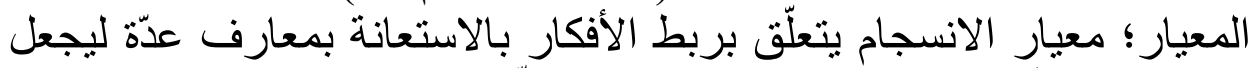

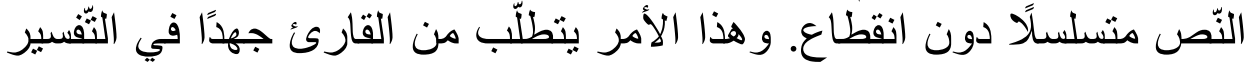

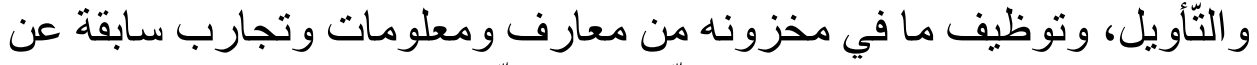

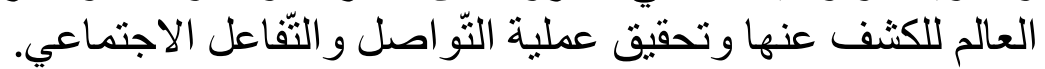

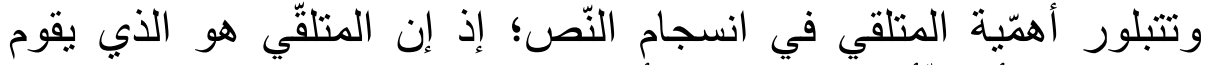

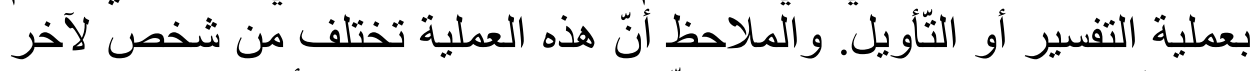

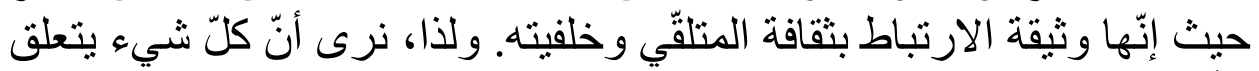

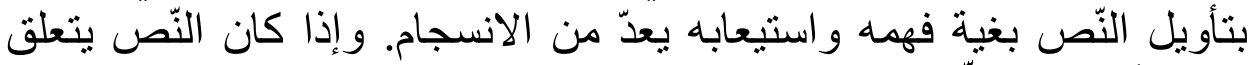

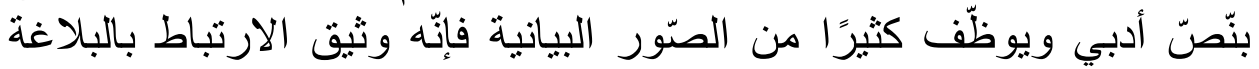

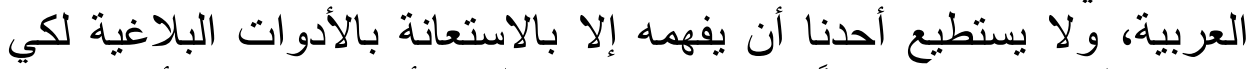

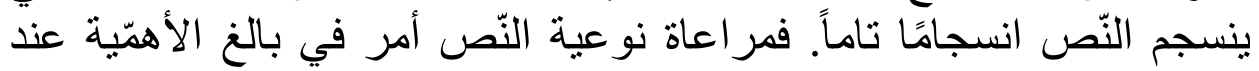

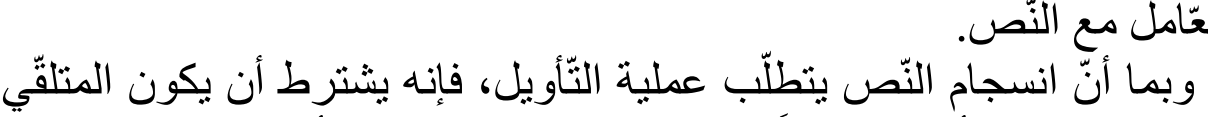

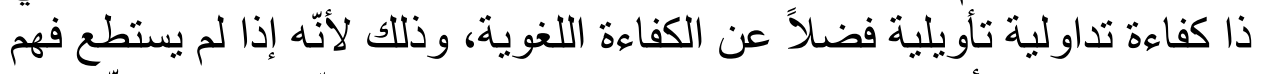

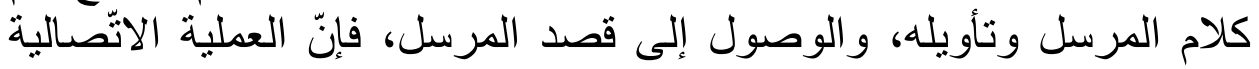




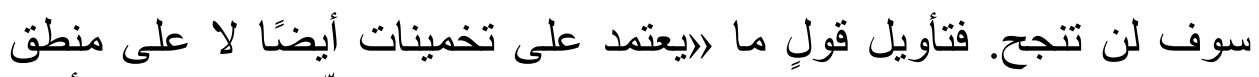

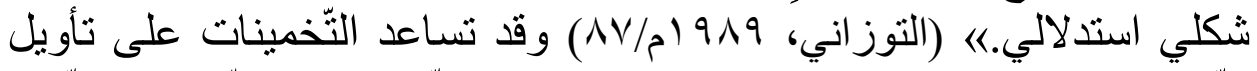

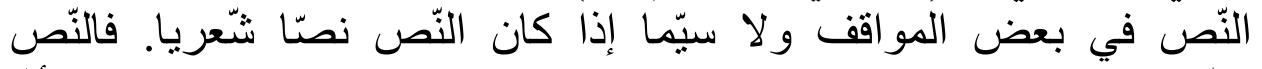

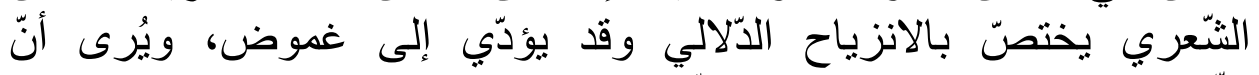

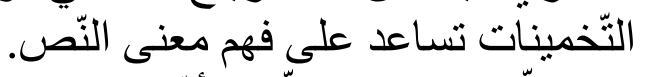

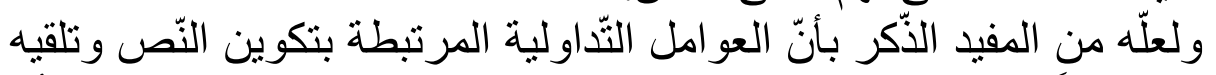

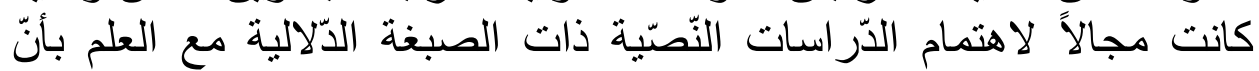

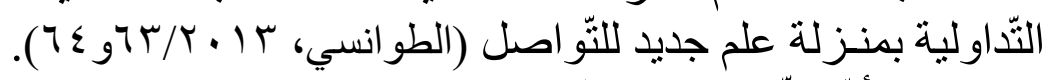

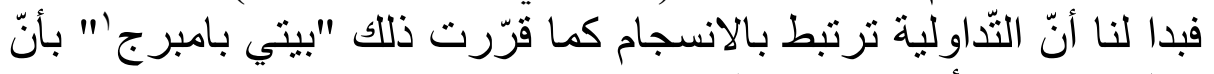

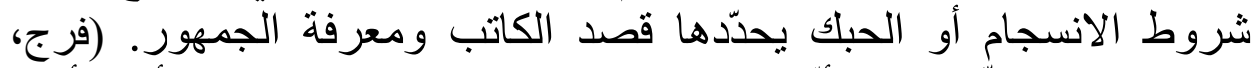

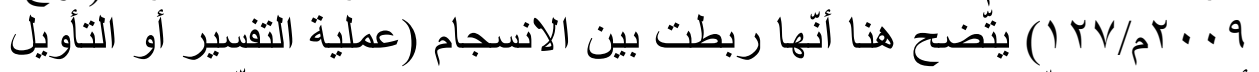

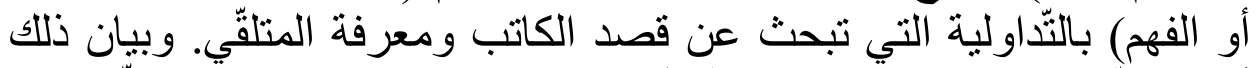

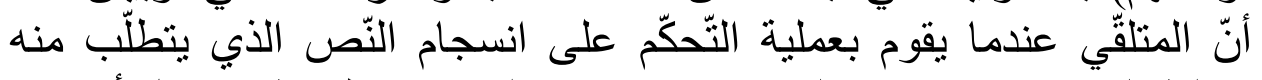

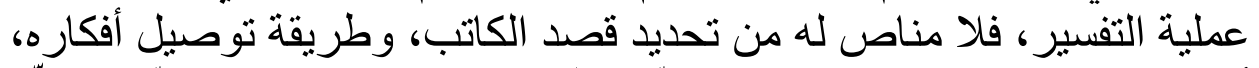

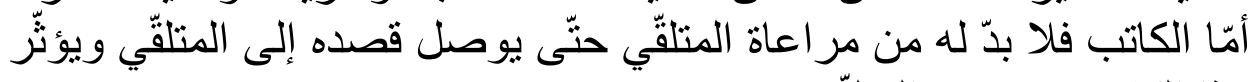
هذا الكلام في نفسه (المنلقّي).

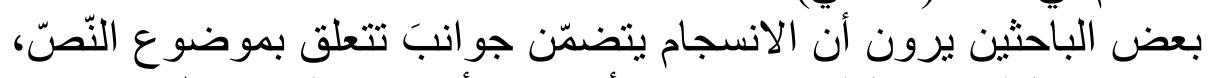

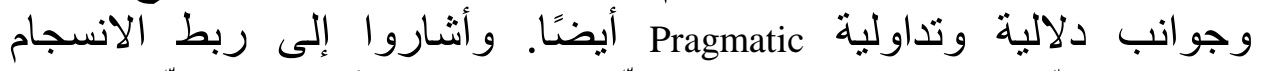

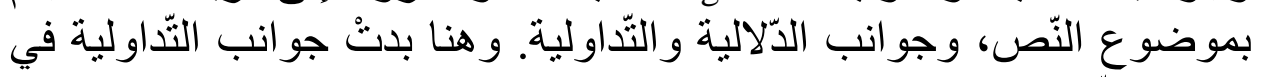

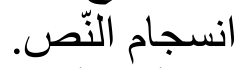
و أمّا "ألان مو" Alden Moe فذكر في مقاله إنّ الحبك (الانسجام) يرتبط به الأنه

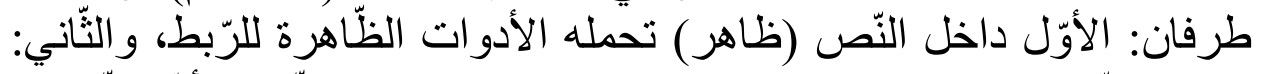

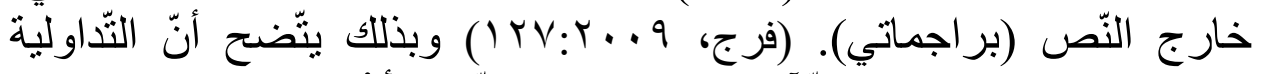

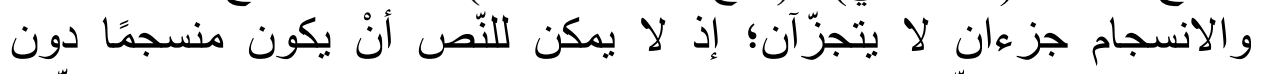

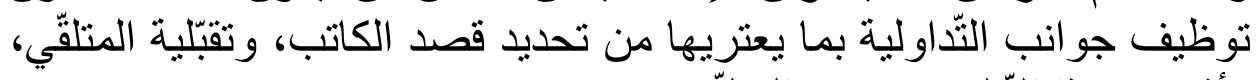

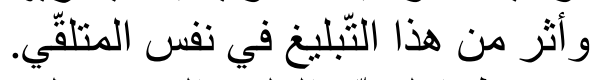

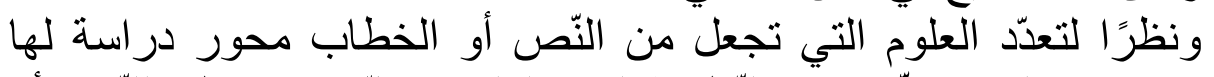

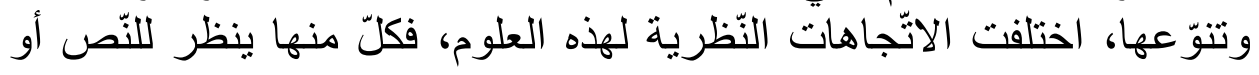




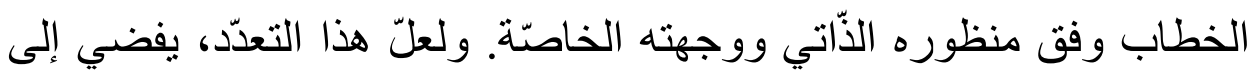
تباين آر اء علماء النّص حول عمليات الانسجام ومعاييره.

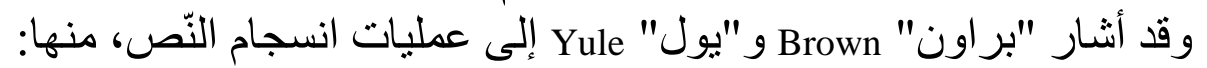

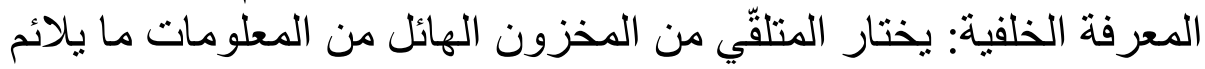

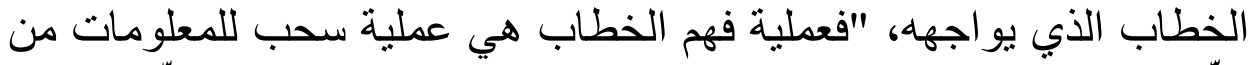

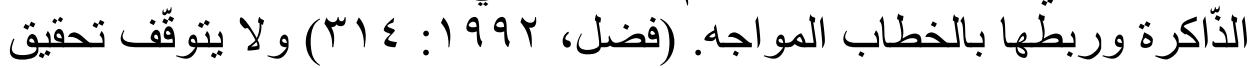

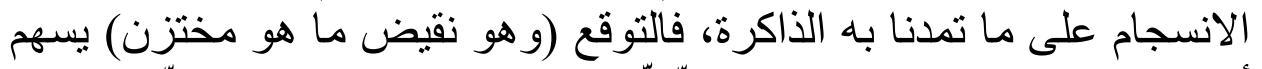

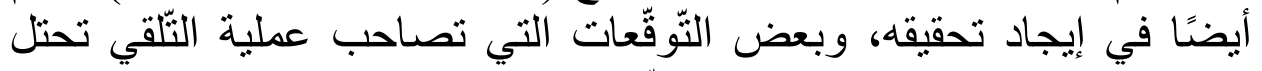

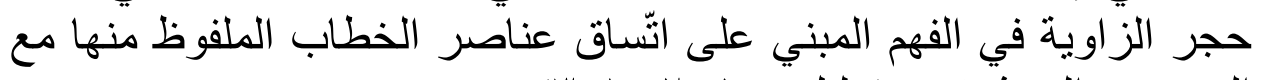

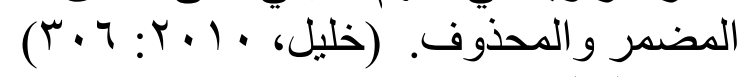

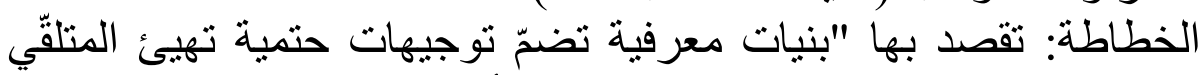

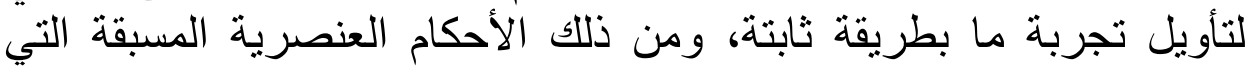

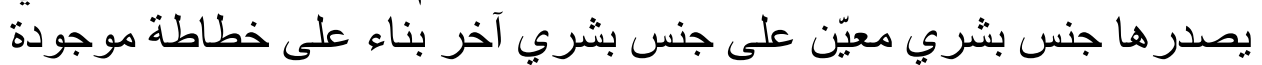

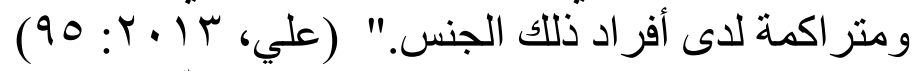

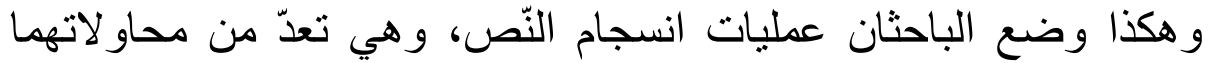

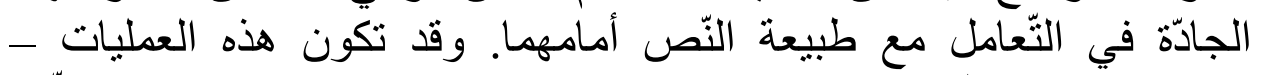

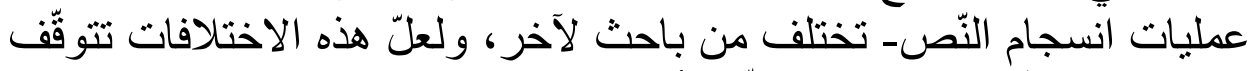

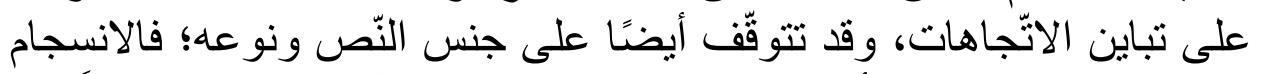

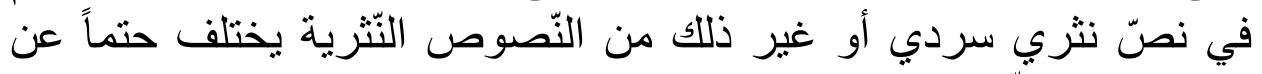

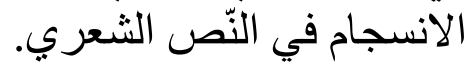

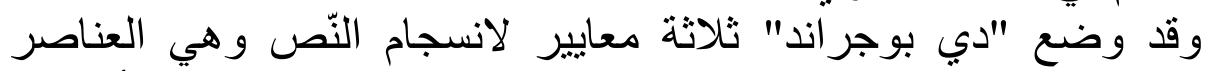

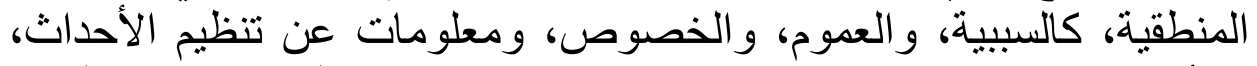

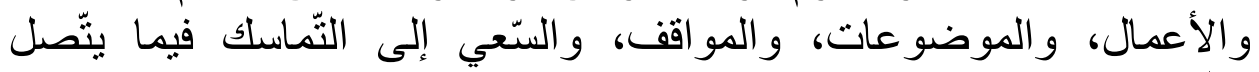

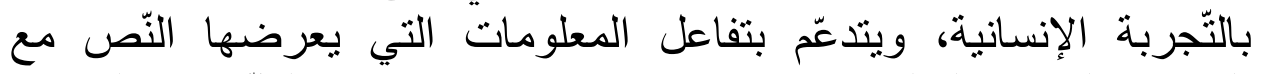

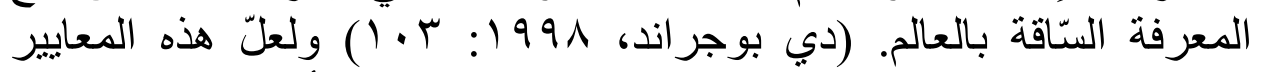

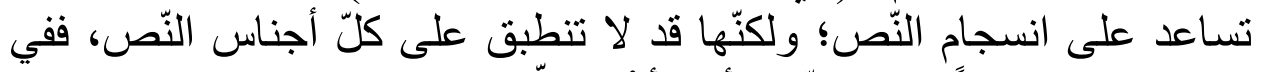

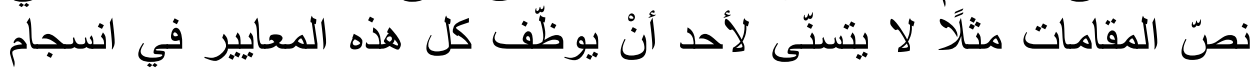

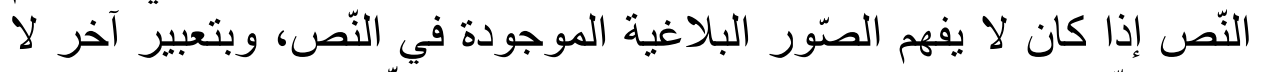

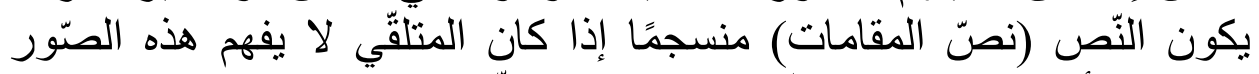

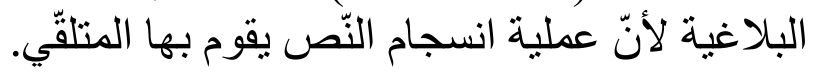




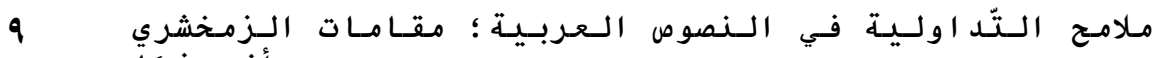

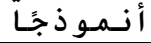

ترتبط البلاغة و الاتّصلال ارتباطًا قويَّا. فالاتّصال يتضمّن ثثلاثة أركان مهمّة

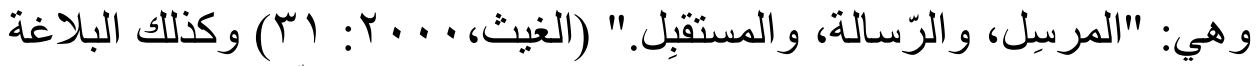

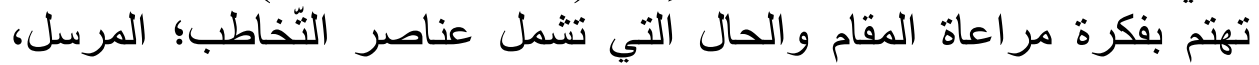

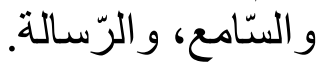

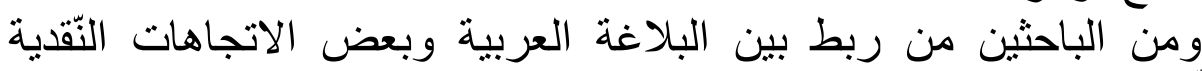

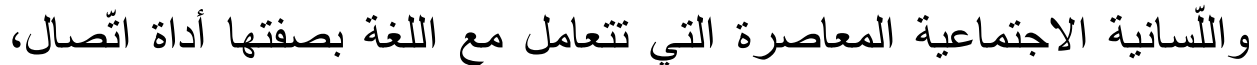

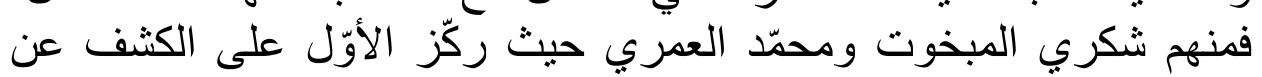

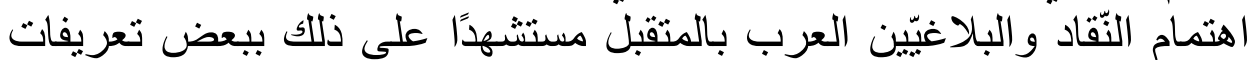

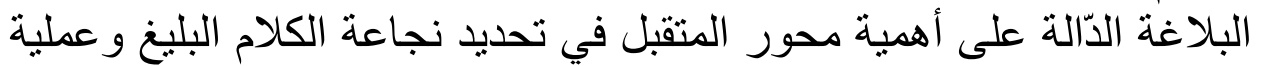

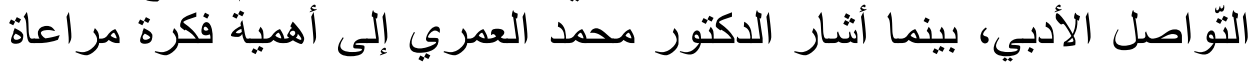

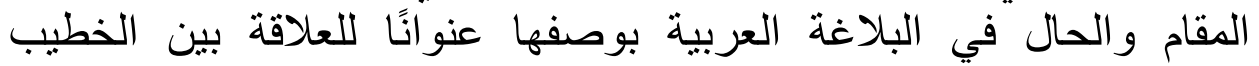

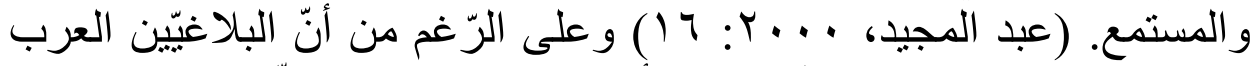

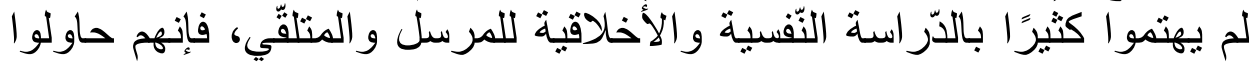

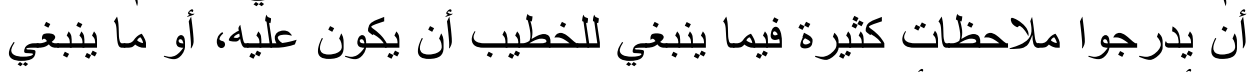
له أن يراعيه من أحوال المستمعين تحت عنوان المقان المقام والحال.(المصدر نفساه)

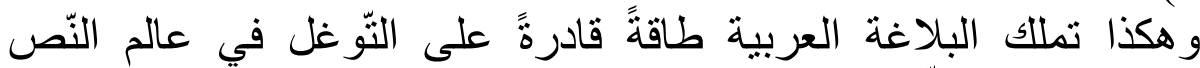

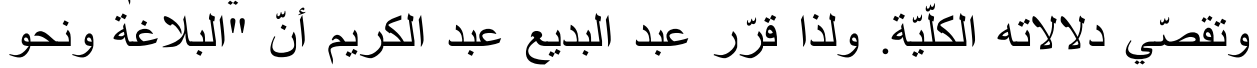

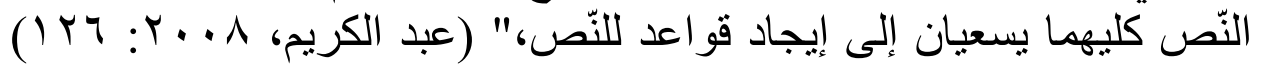

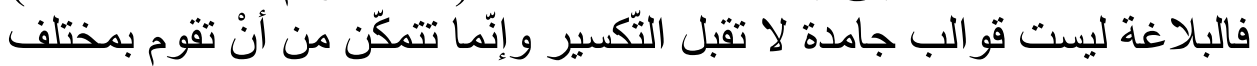

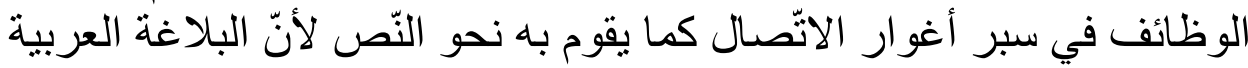

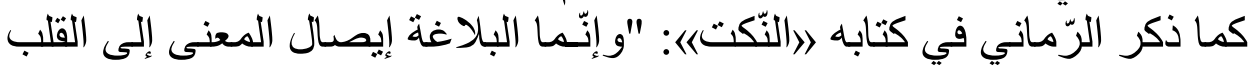

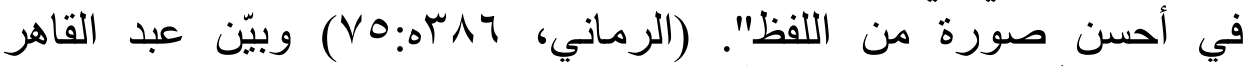

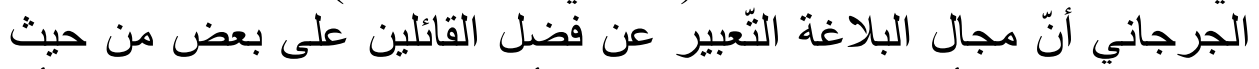

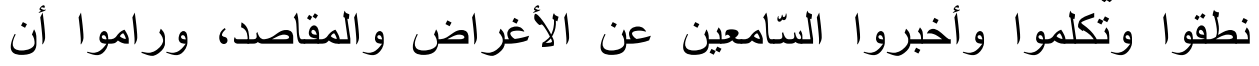

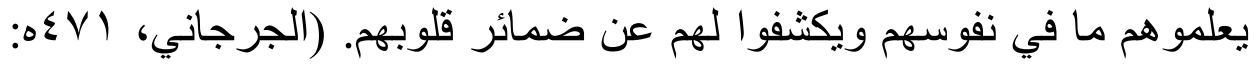

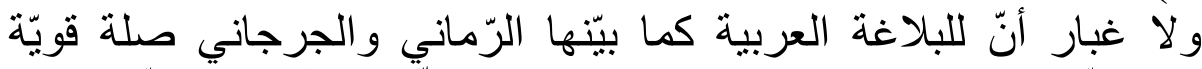

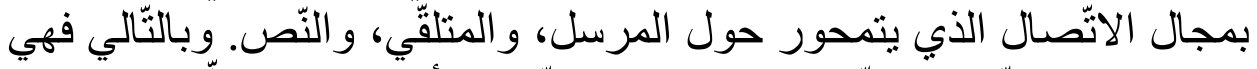

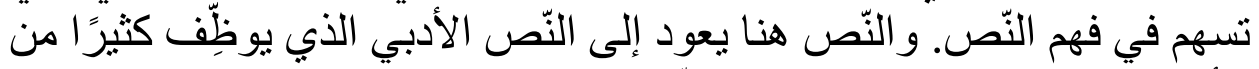

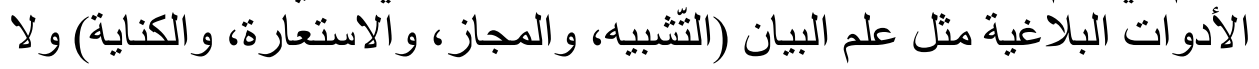


يستطيع أحد أن يفهم ذلك النّص، ويفسّره، ويؤوّرله دون اكتناه هذا العلم، وهو

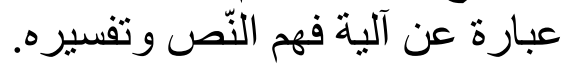

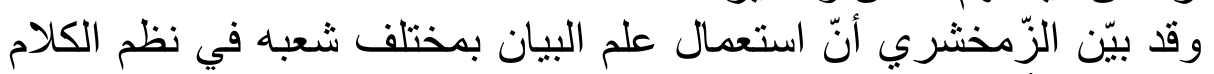

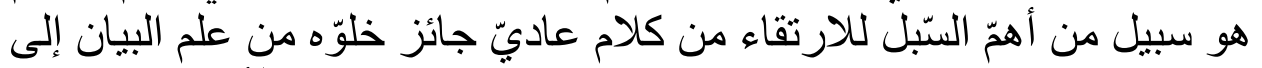

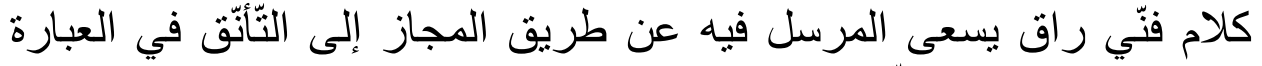

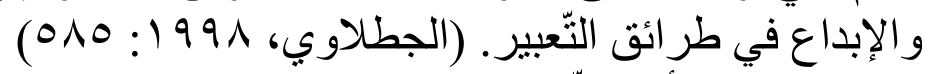

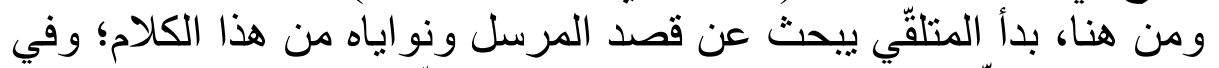

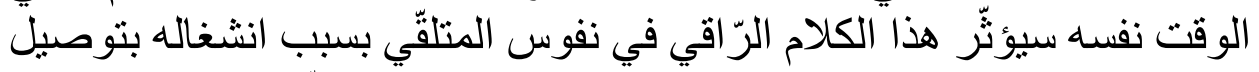

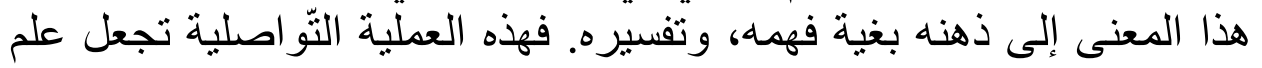

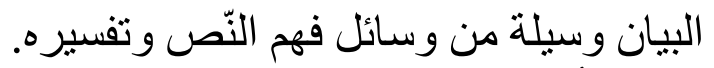

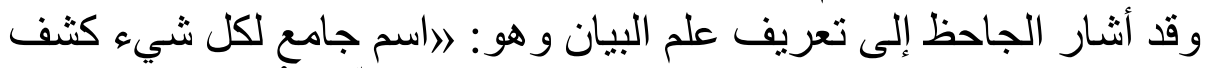

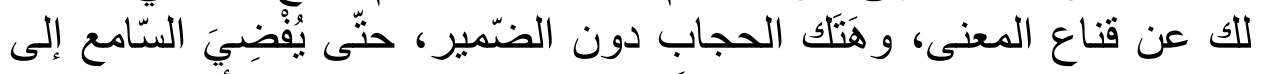

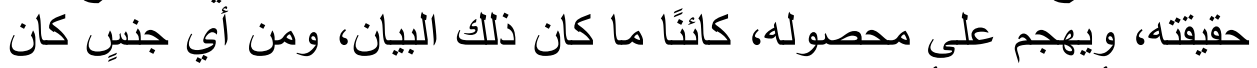

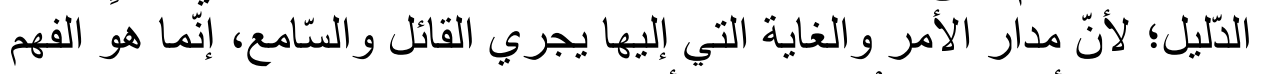

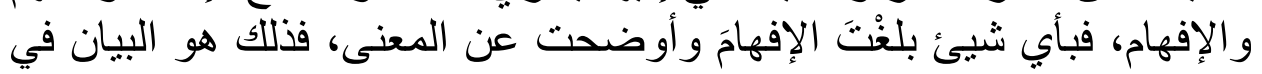

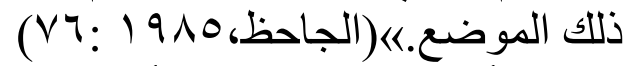
وقد أوضتح الجاحظ هنا أنّ غاية علم البيان الفهم والإفهام، من المتلقِي

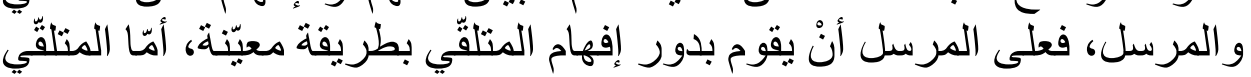
فيقوم بعملية فهم هذا الكلام. و علم البيان (التّشبيه، و المجاز ، و الاستعارة، و الكناية) كما عرّفه السّكاكي

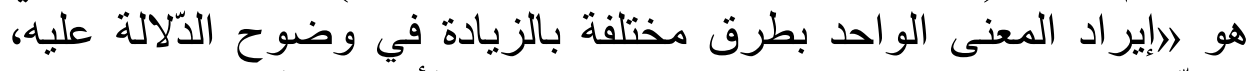

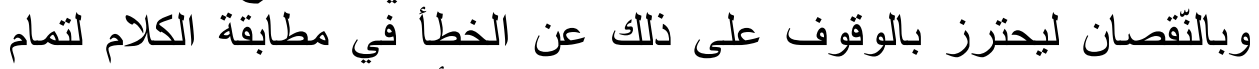

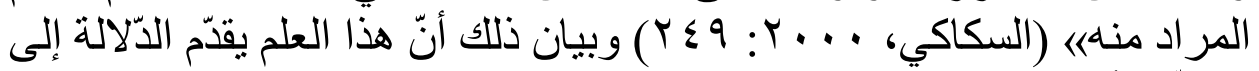

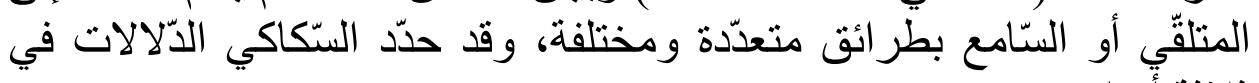

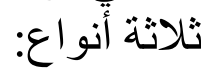

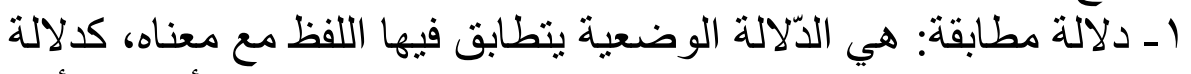

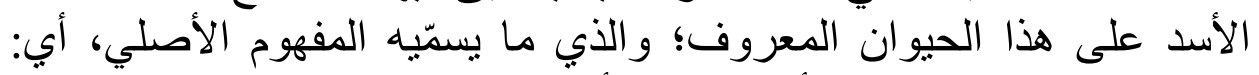

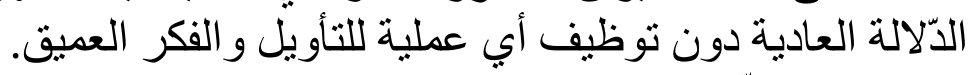

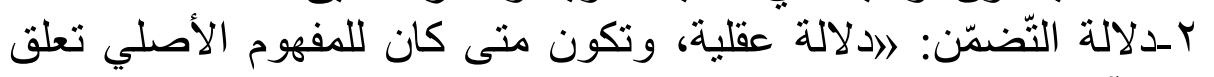
بمدلول آخر داخل فيه، كدخول السّقف في مفهوم لفظ البيتهاء. (السلفّاوي، 


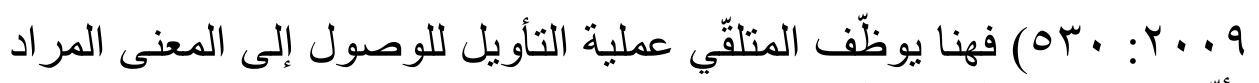

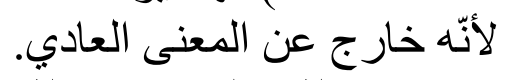

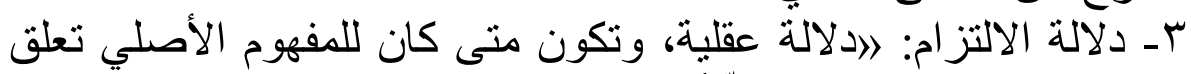

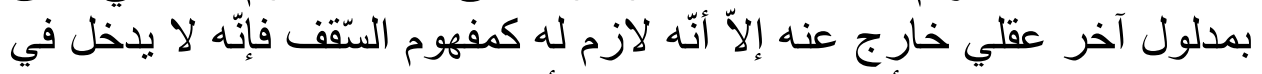

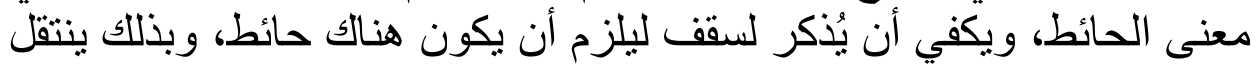

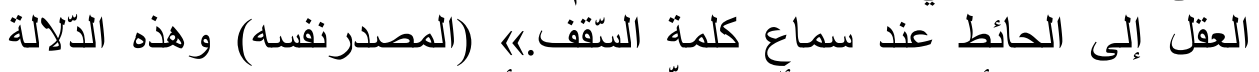

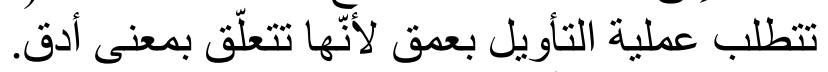

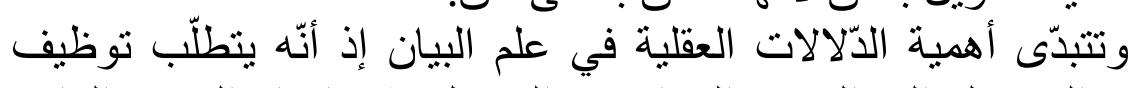

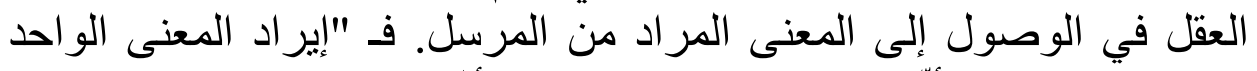

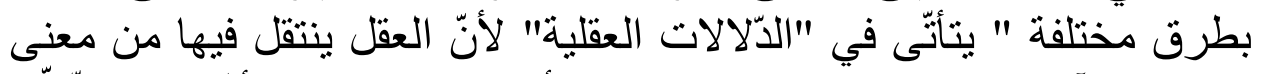

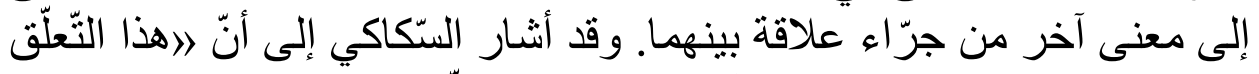

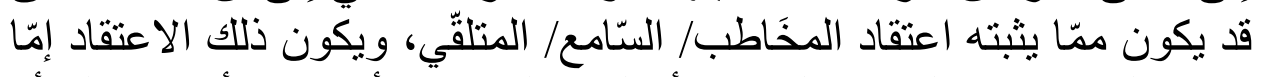

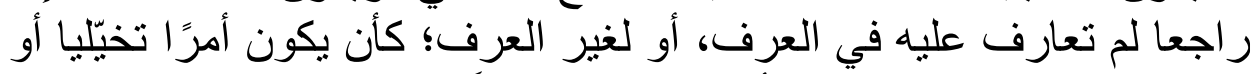

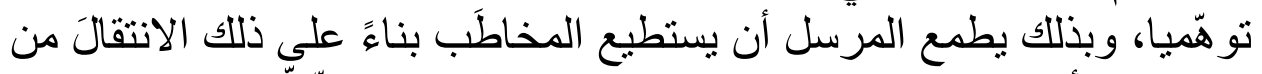

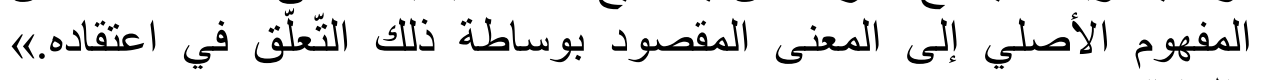

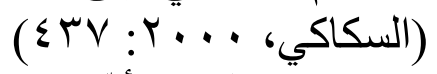

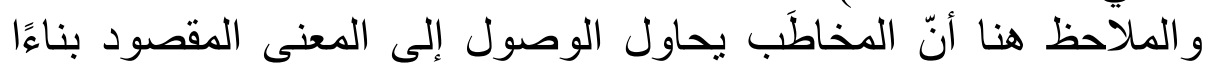

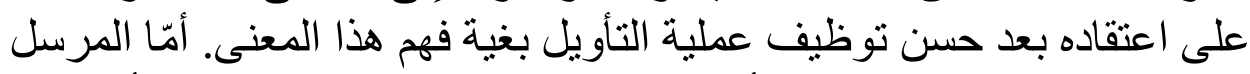

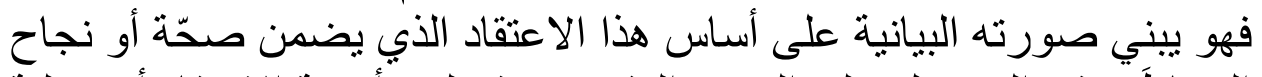

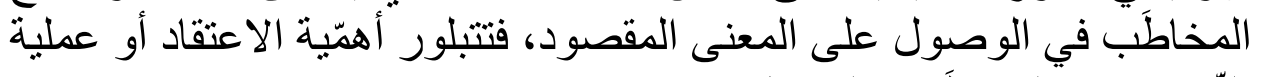
التّخمين من المخاطَّ و المرسل.

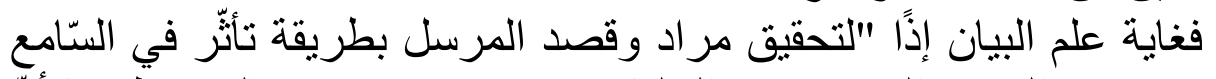

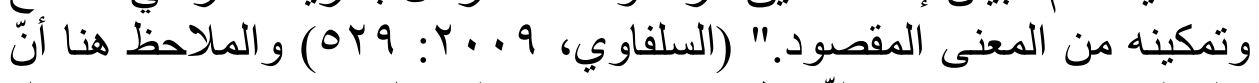

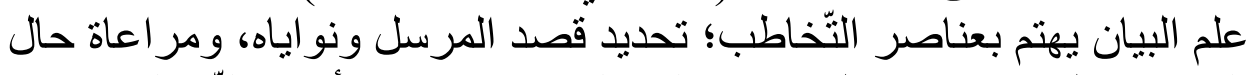

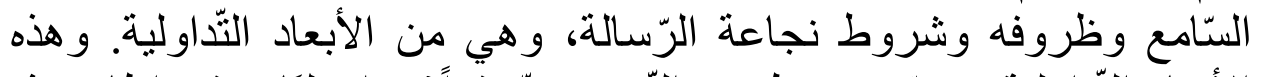

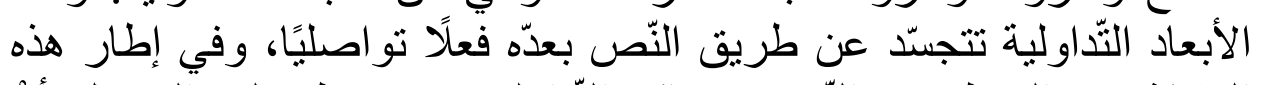

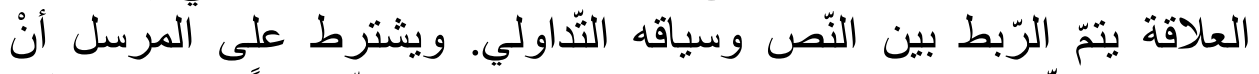

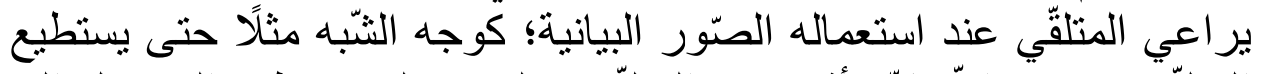

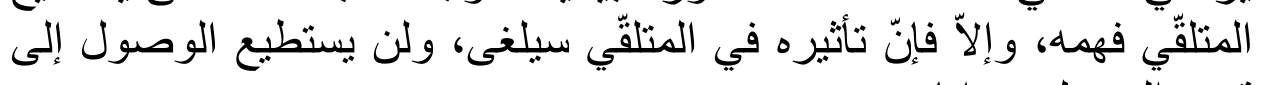
قصد المرسل ونو اياه. 
وتجدر الإشارة إلى أنّ هذا العلم يعتني بالانزياح الدّلالي، وهو يؤدّي دورًا

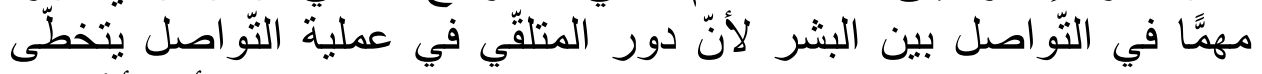

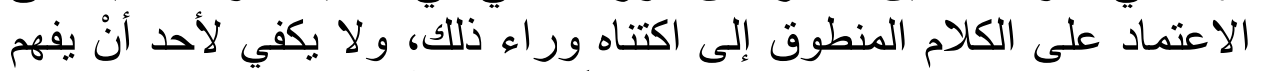

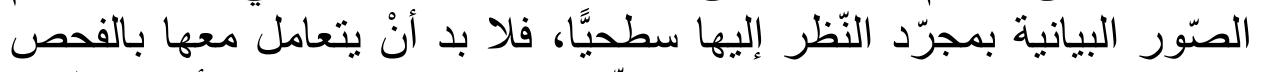

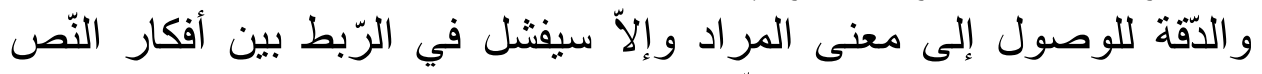

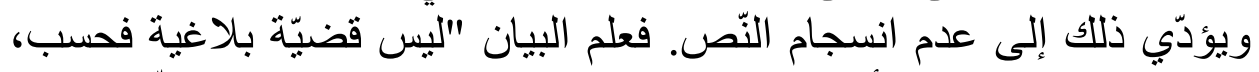

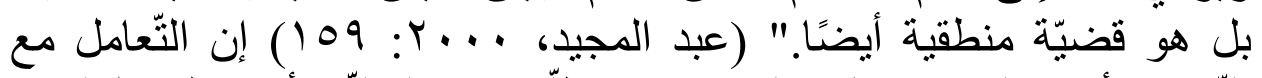

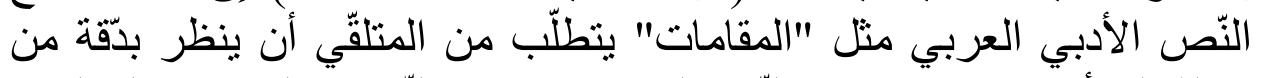

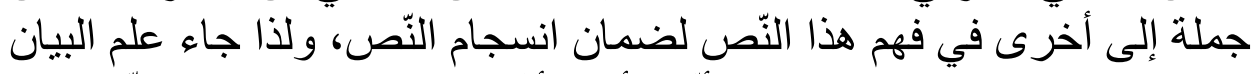

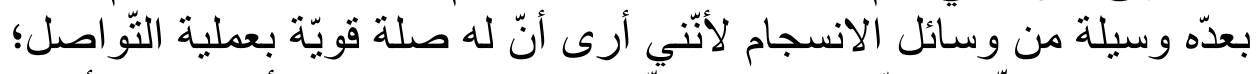

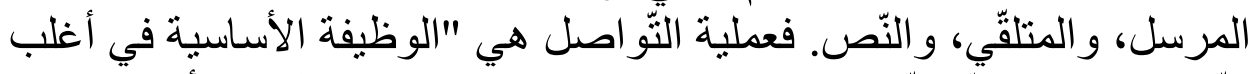

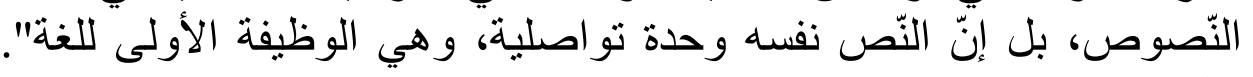

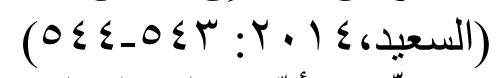

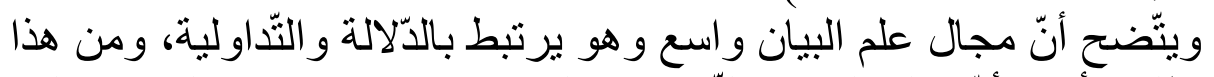

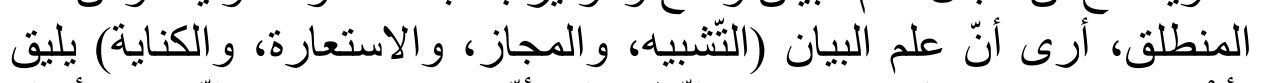

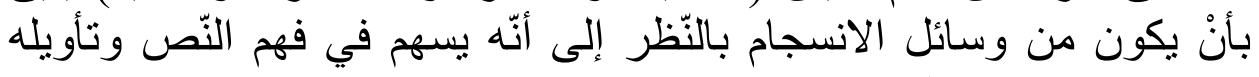

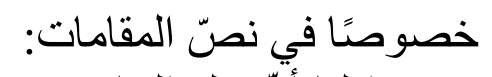

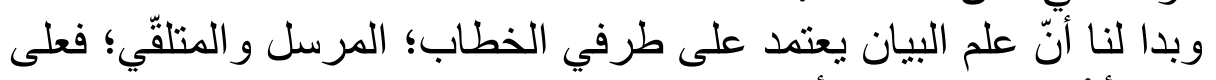

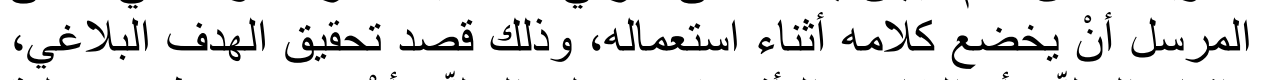

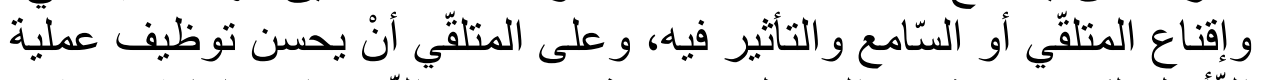

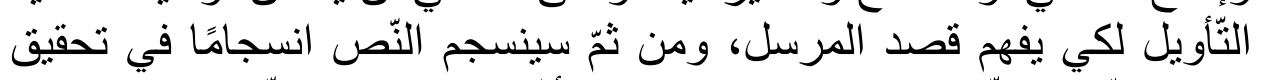

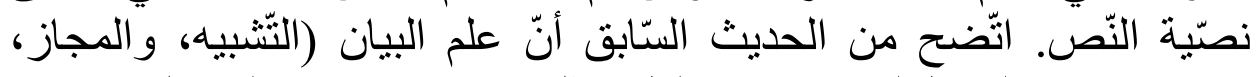

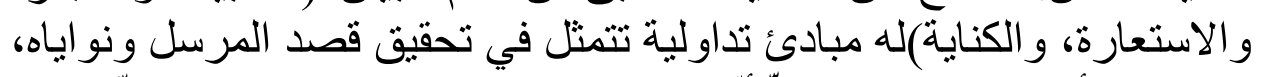

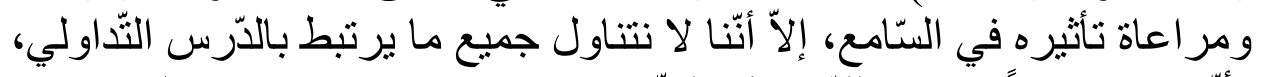

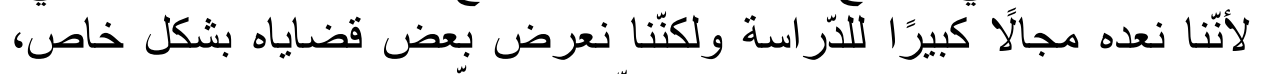

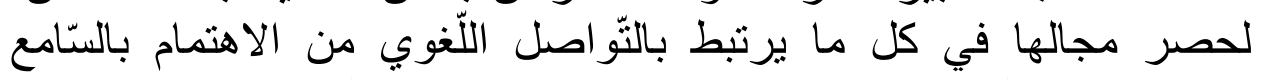

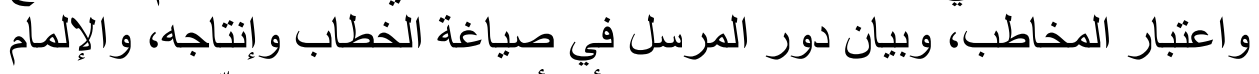

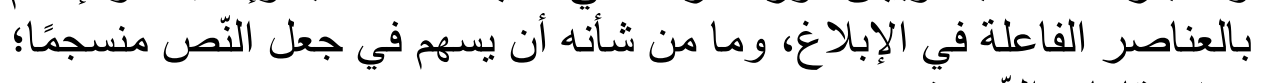

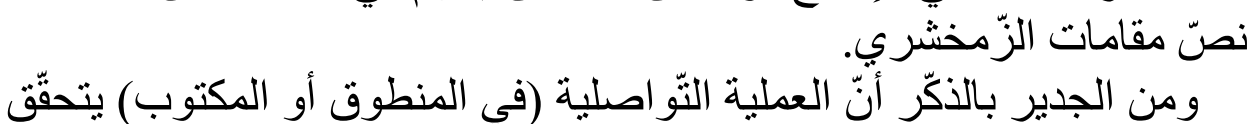

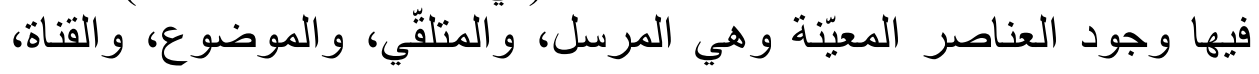




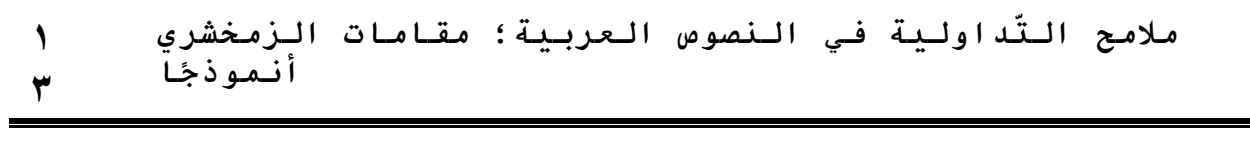

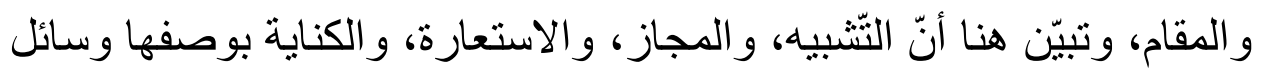

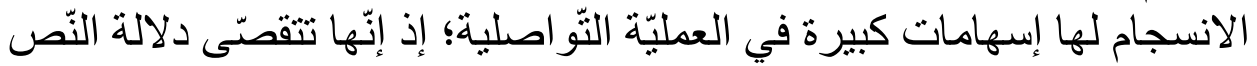

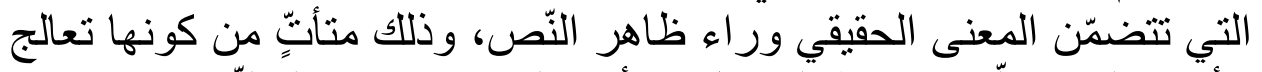

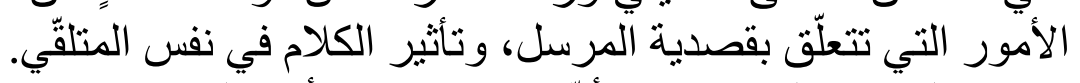

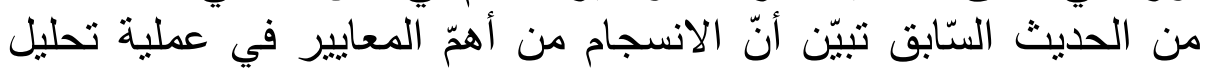

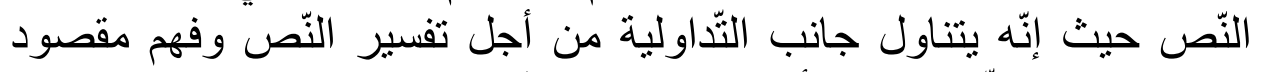

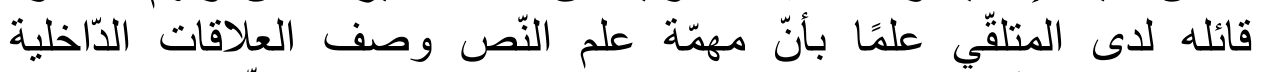

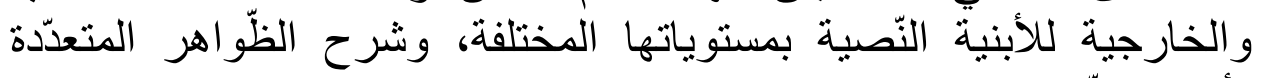

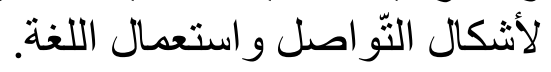

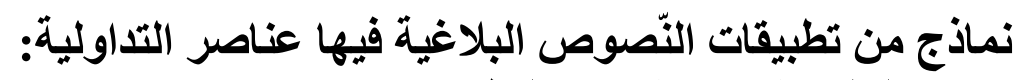
في التالي نذكر نماذج من التطبيقات:

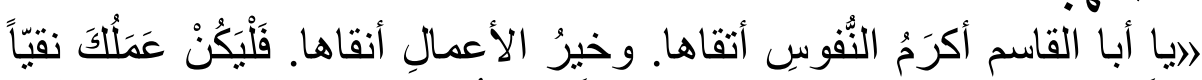

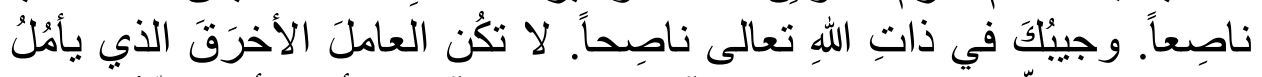

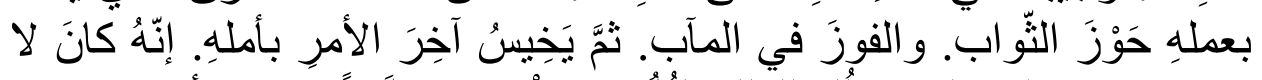

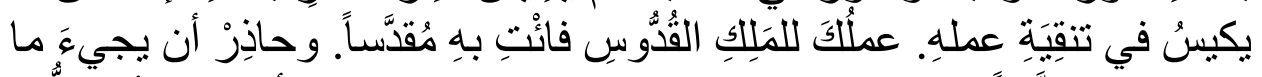

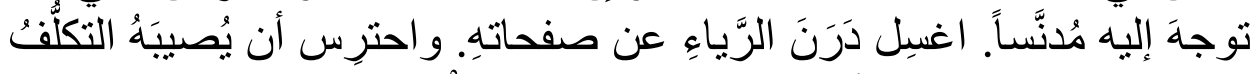

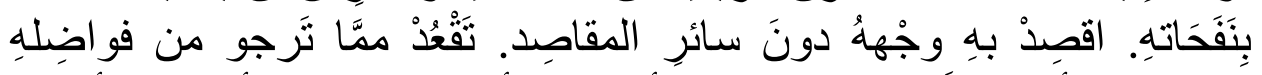

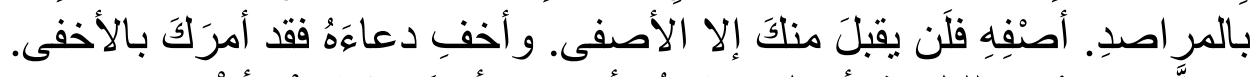

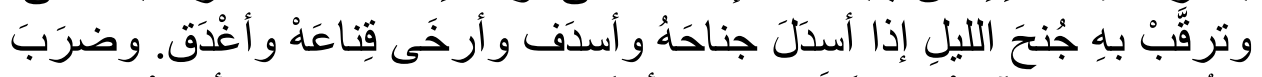

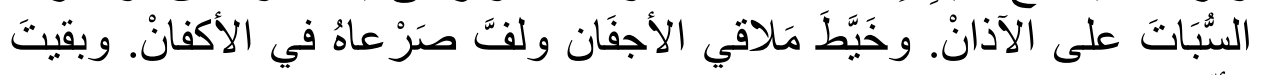

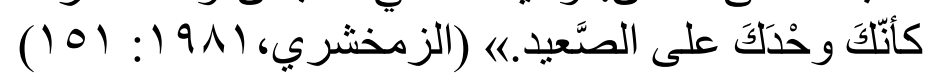

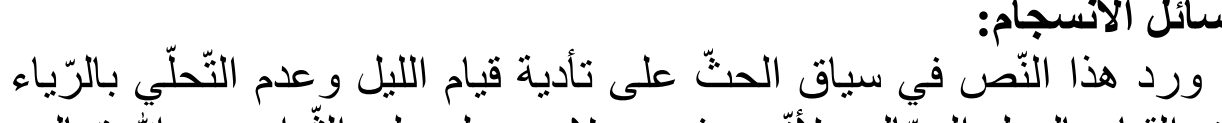

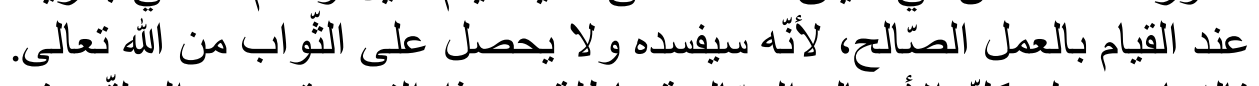

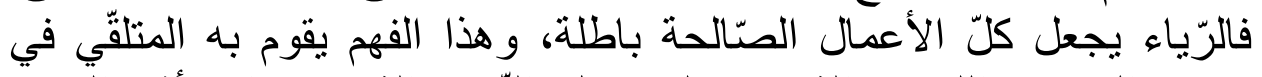

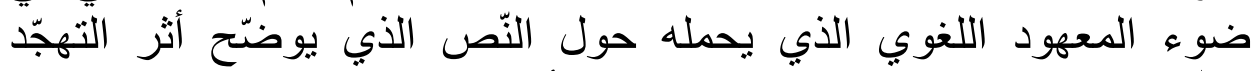

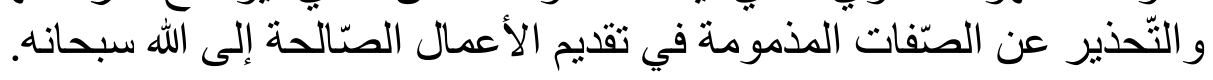




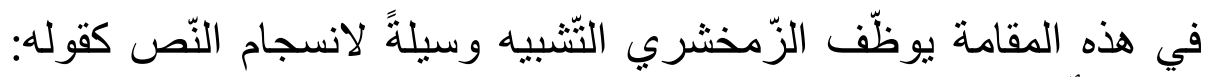

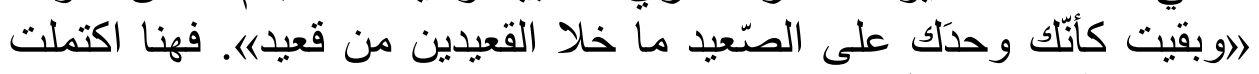

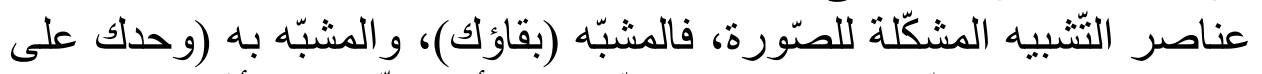

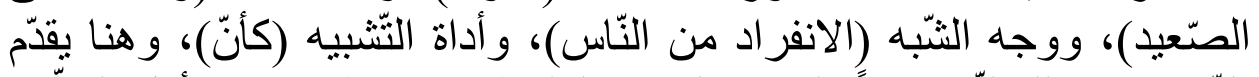

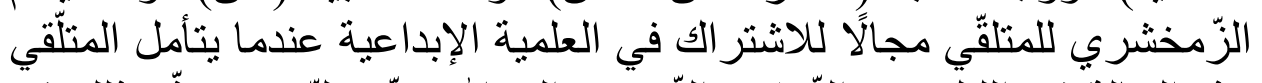

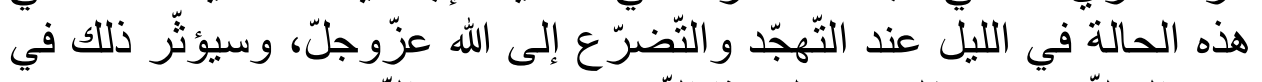

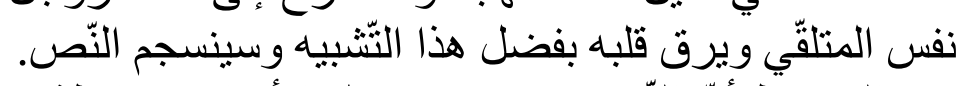

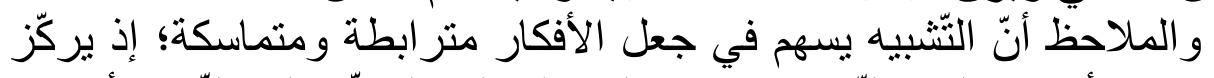

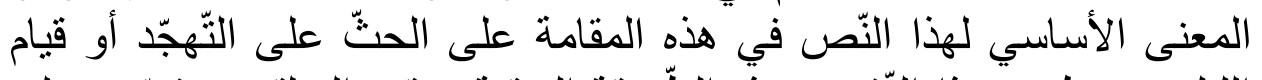

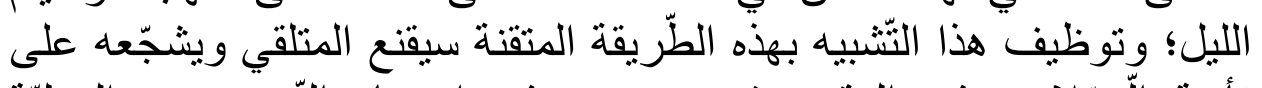

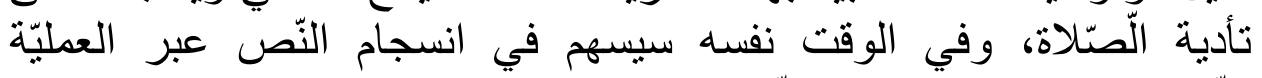

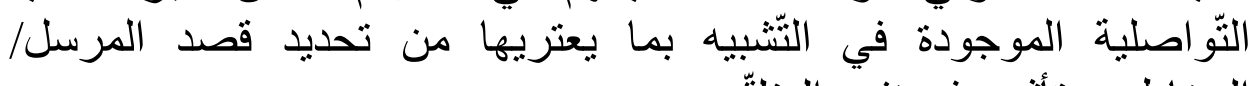
المخاطب وتأثثيره في نفس المنلقّي.

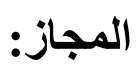

استعمل الزّمخشري المجاز كثثرًا في هذه المقامة، وتنّضّح وظيفته بشكل

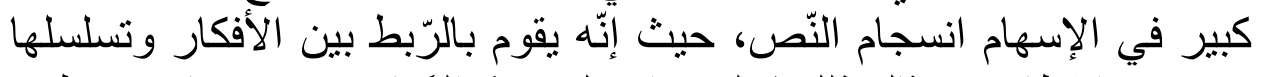

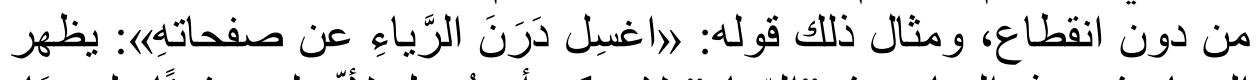

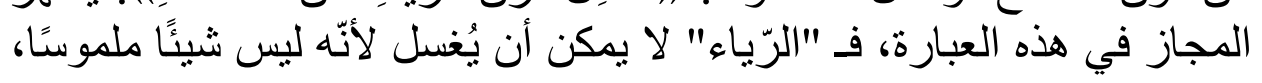

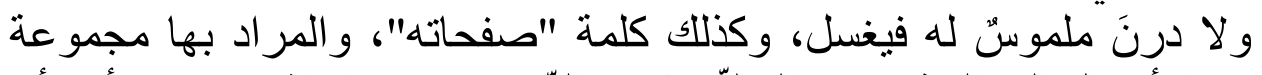

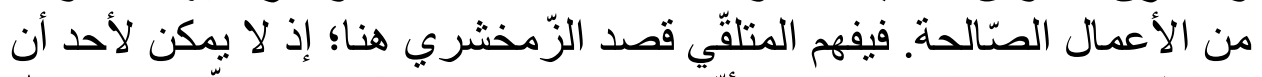

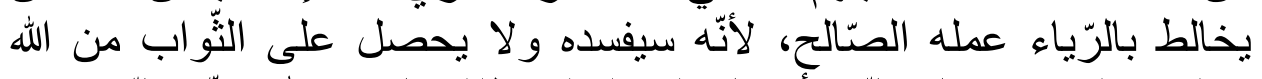

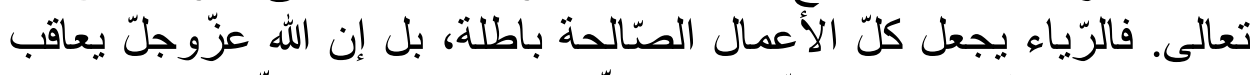

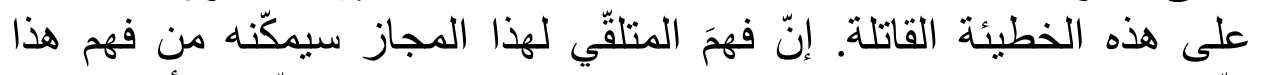

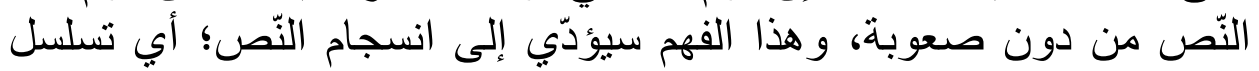

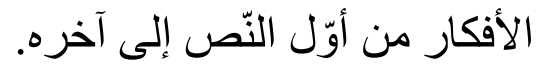

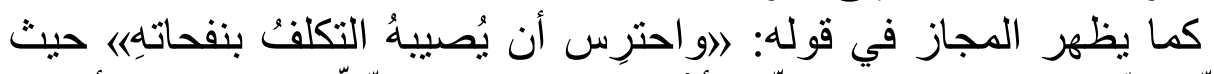

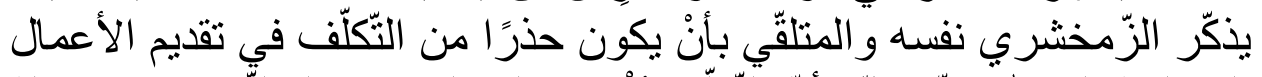

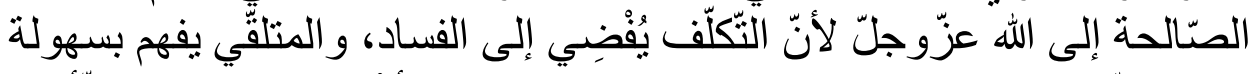

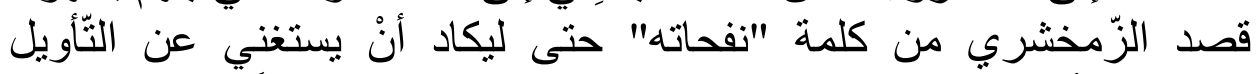

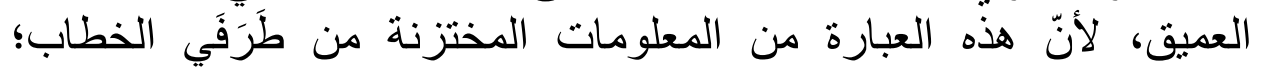




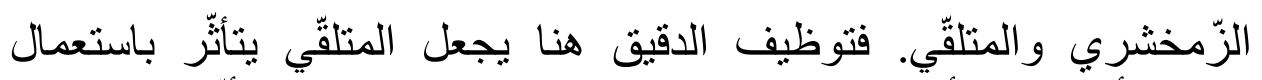

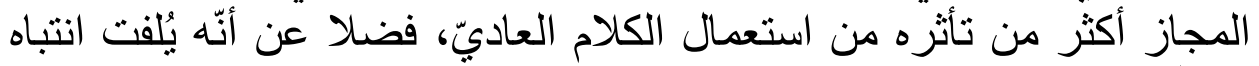

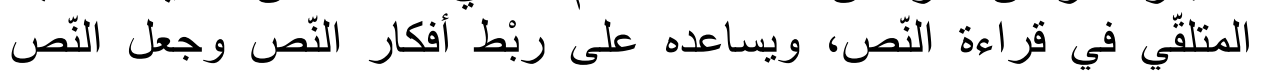
منسجمًا.

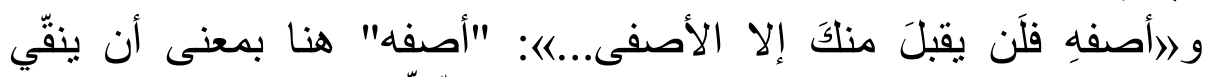

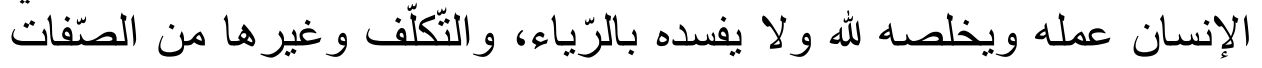

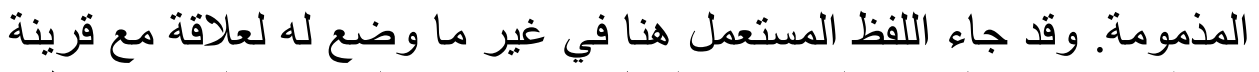

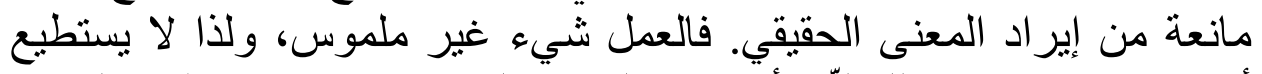

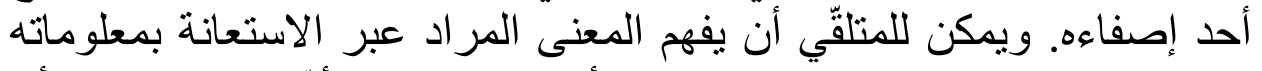

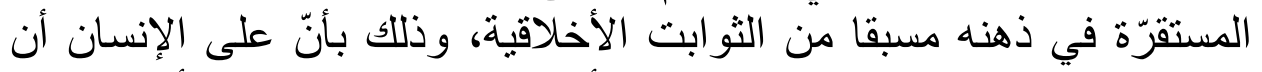

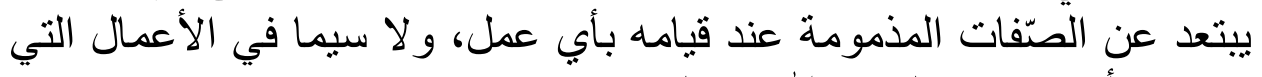

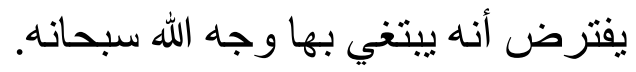

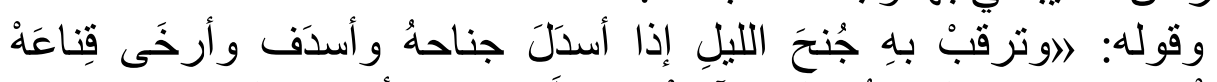

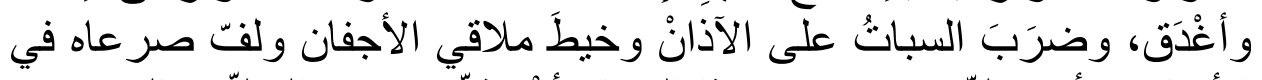

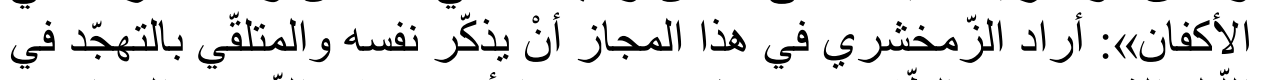

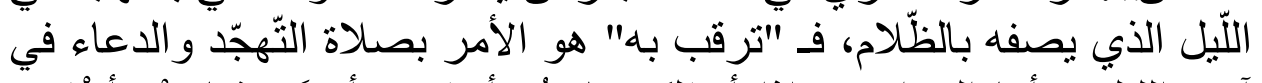

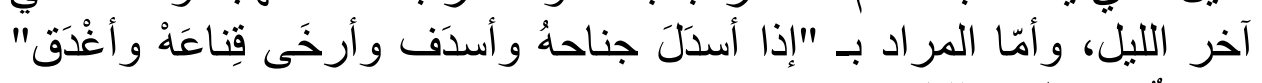

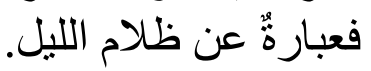

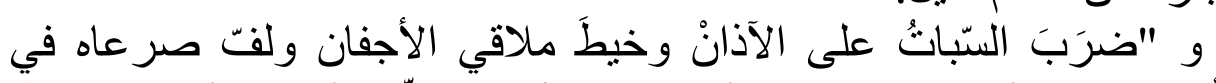

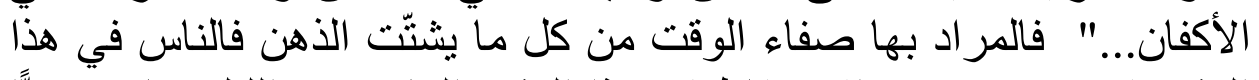

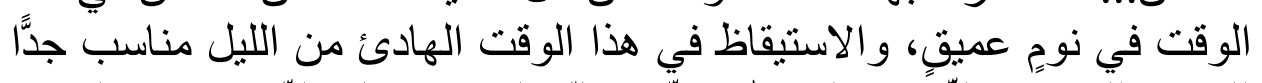

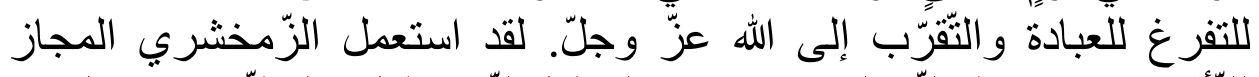

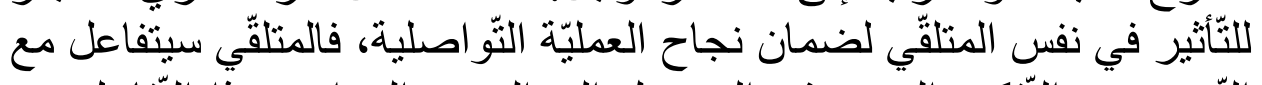

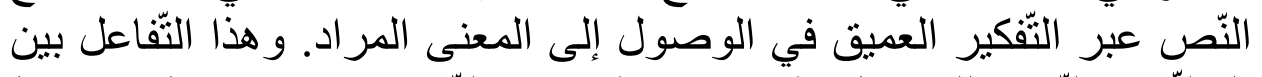

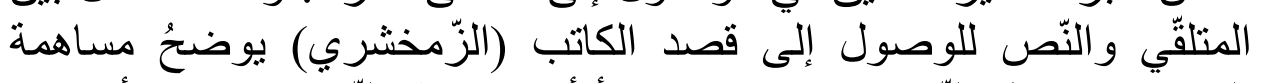

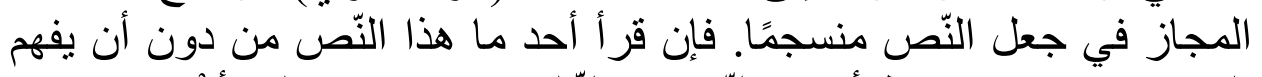

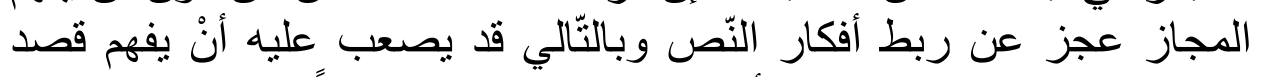

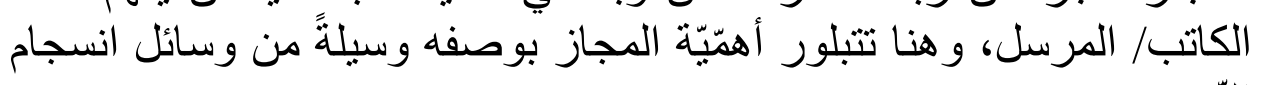




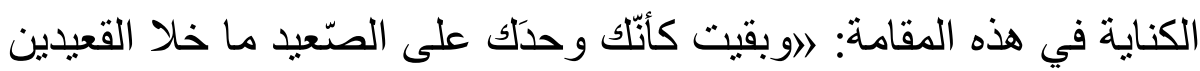

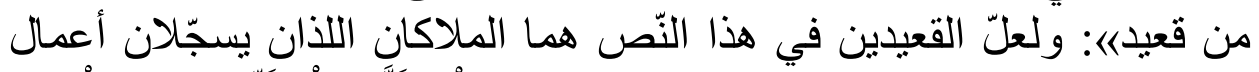

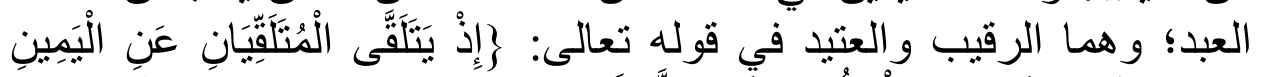

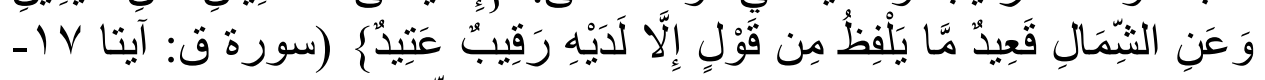

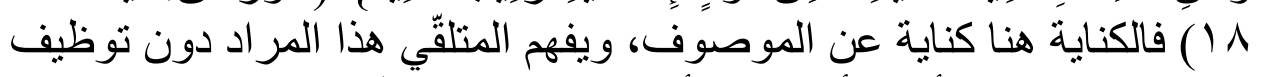

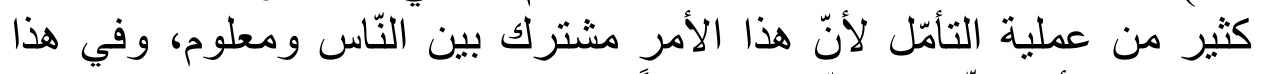

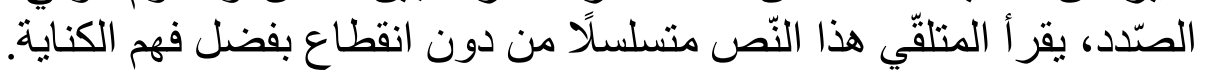

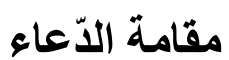

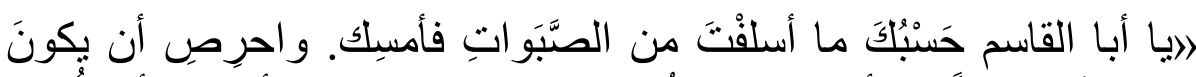

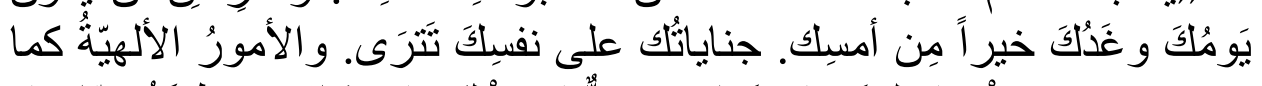

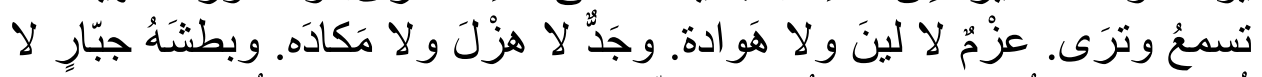

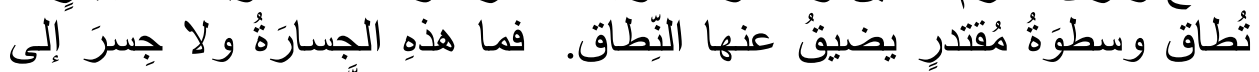

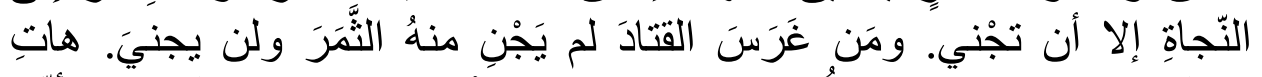

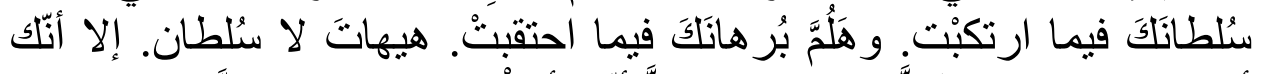

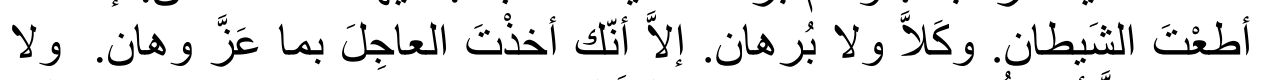

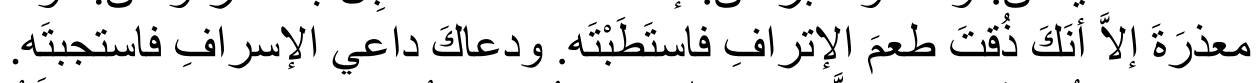

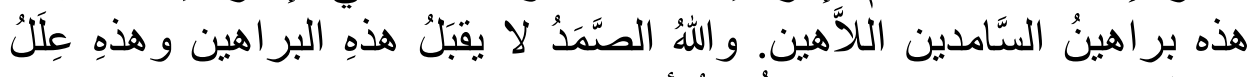

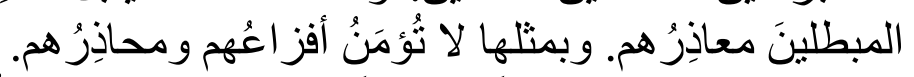

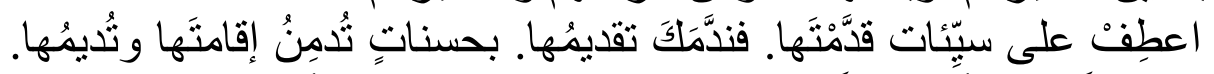

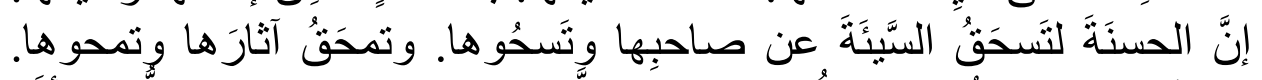

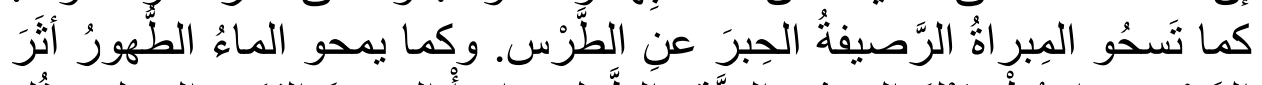

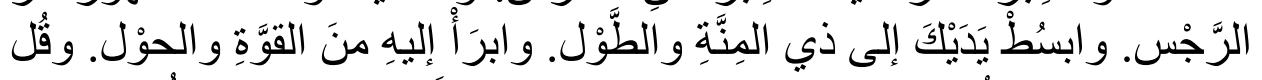

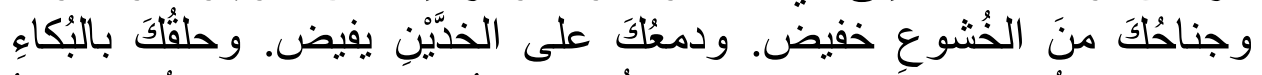

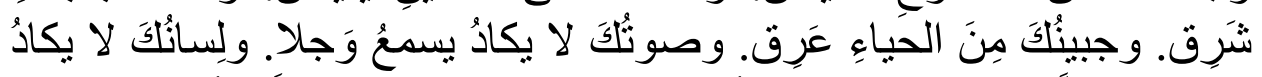

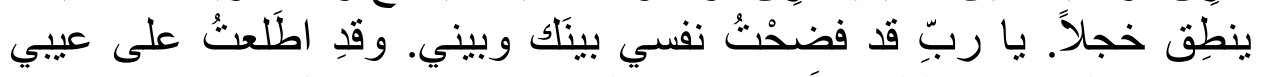

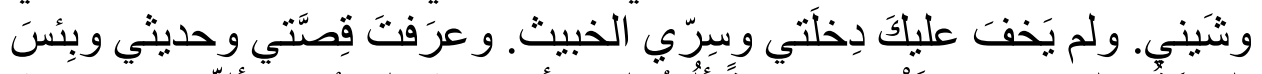

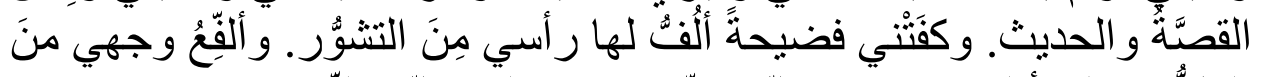

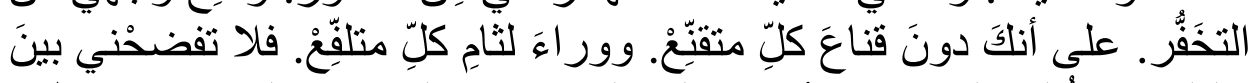

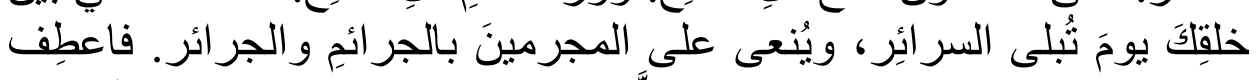

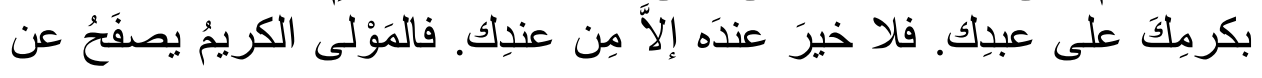




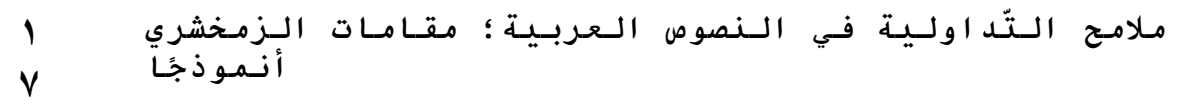

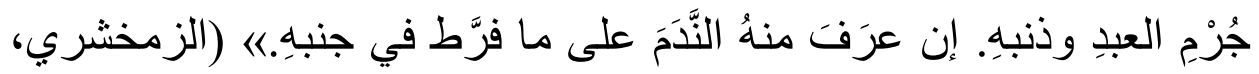
(107: 1914

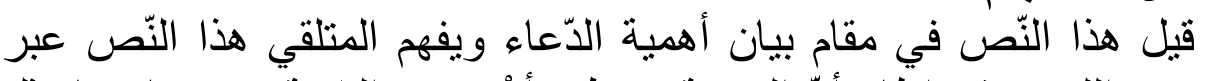

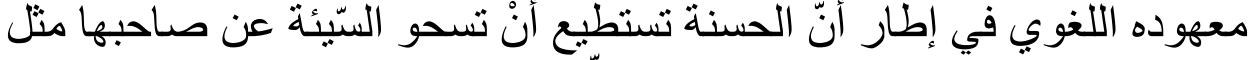

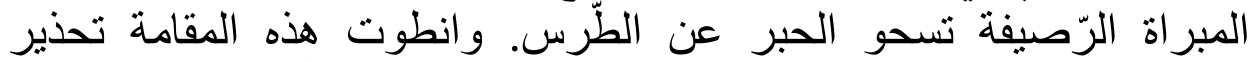

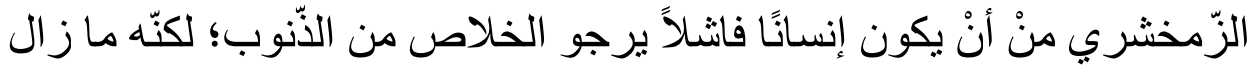

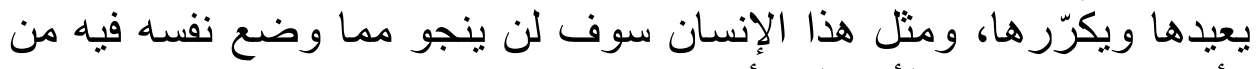

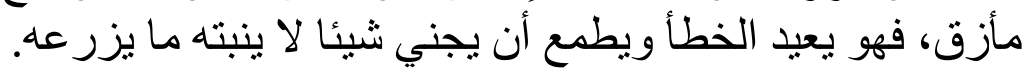

يُلحظظة في هذه المقامة استعمال التّّبيه كما في قول الزّمخشري: إإنَّ

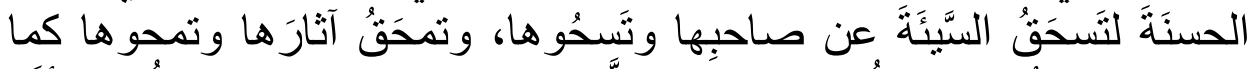

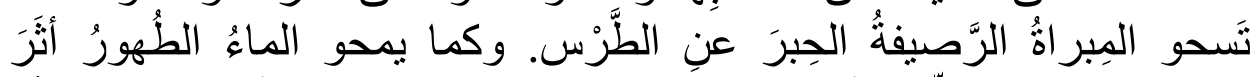

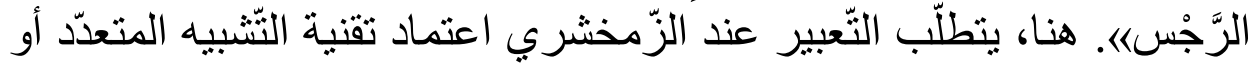

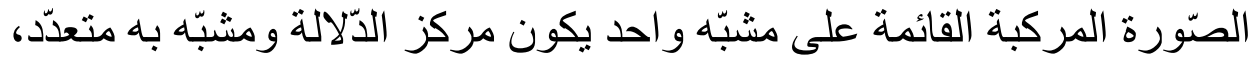

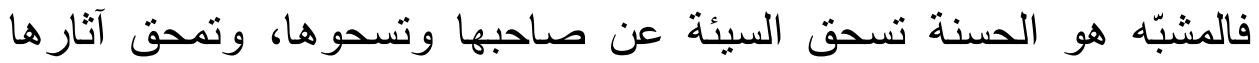

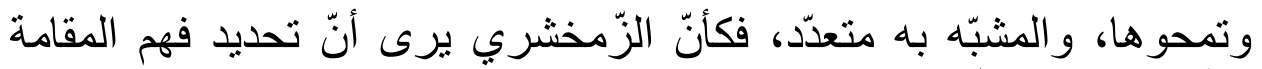

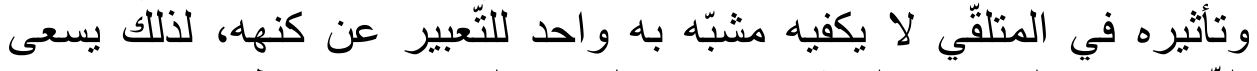

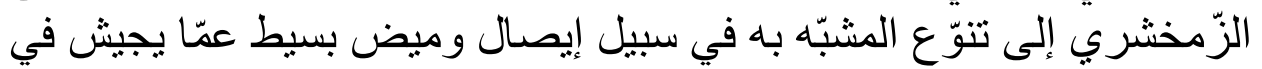
خاطره في المقامة.

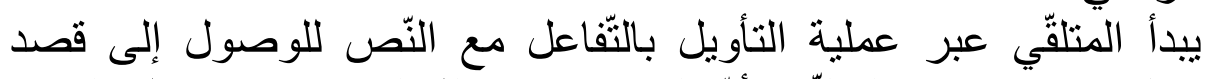

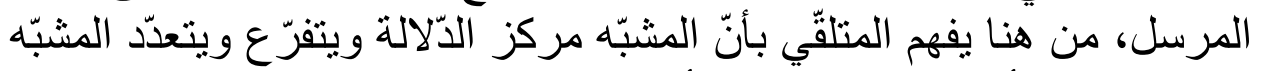

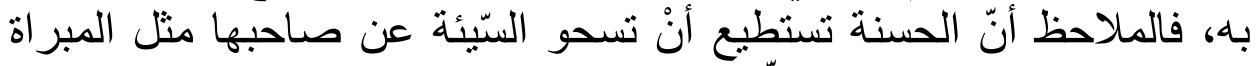

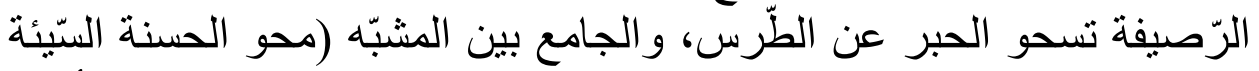

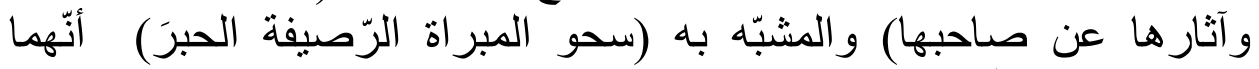

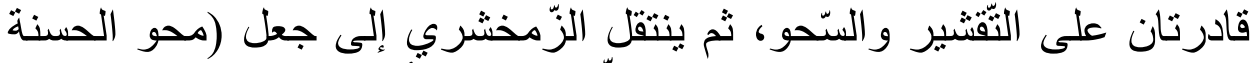

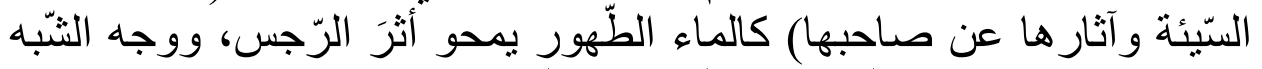
بينهما هو القدرة على التّظيف و التّطهير و التّّفية.

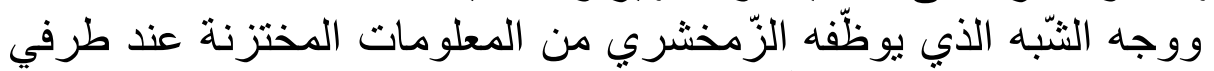

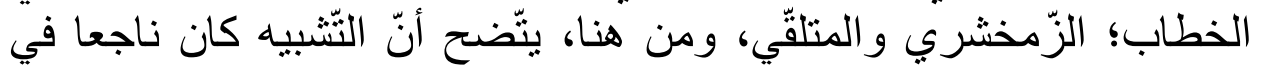


تعاطي صور الكلام، فهو يسعى إلى توكيد المعنى المراد وترسيخه في ذهن

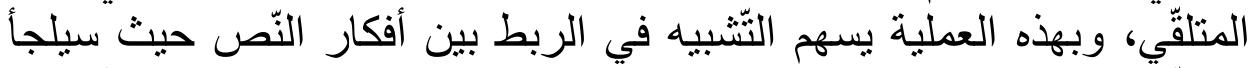

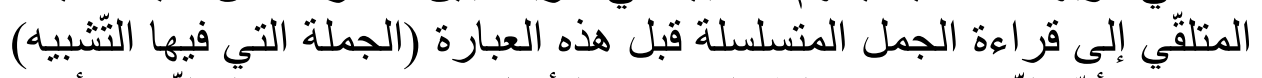

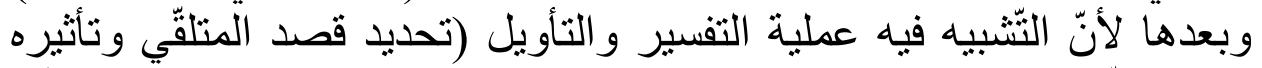

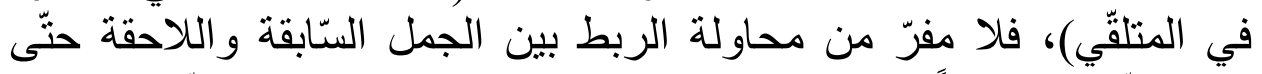
يكون النّص متسلسلًا من دون انقطاع في المعنى لضمان النسان النسام النّص.

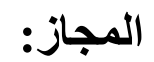

في هذه المقامة توظيف للمجاز في قول الزّمخشري: ارو لا جِسرَ إلى النّجاةِ

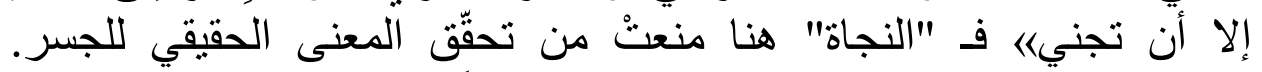

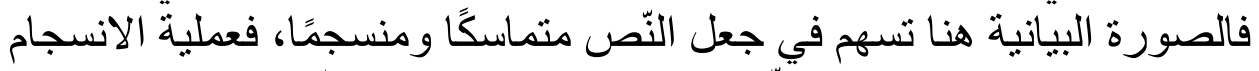

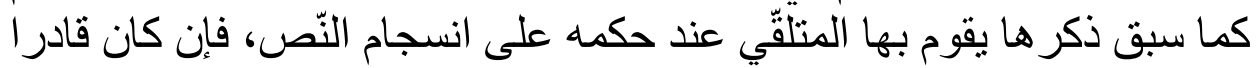

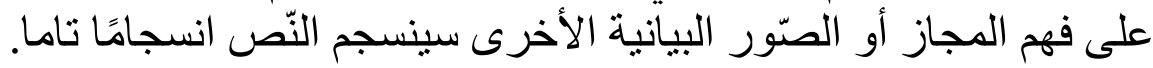

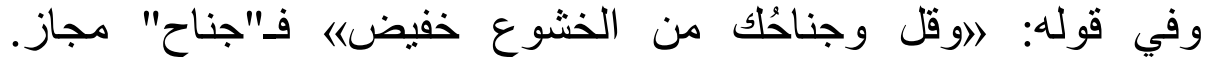

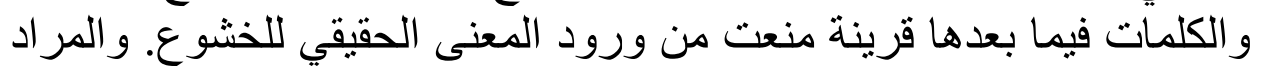

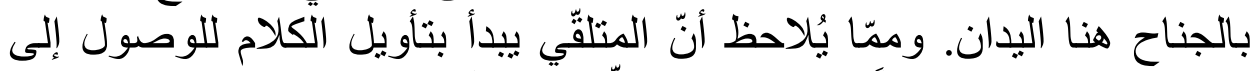

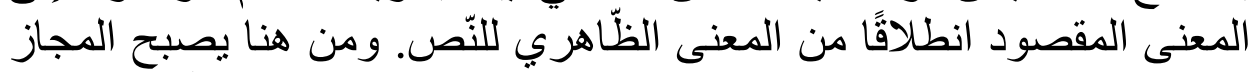

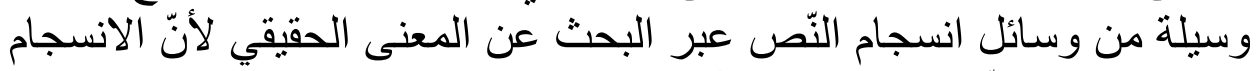
عملية تتجاوز التّحليل السّّطحي للنّص.

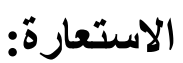
البرزتُّ الاستعارة في هذه المقامة كما في قوله: الاوسطوة مقتدر يضيق عنها

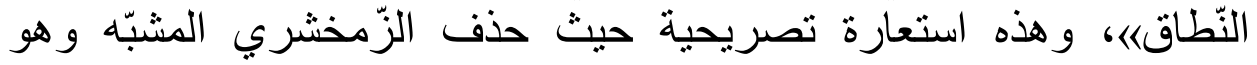

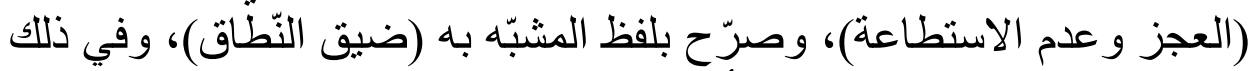

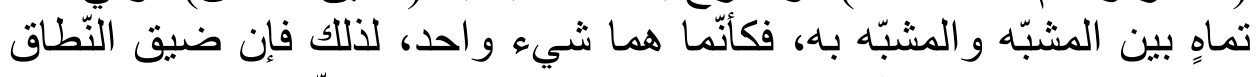

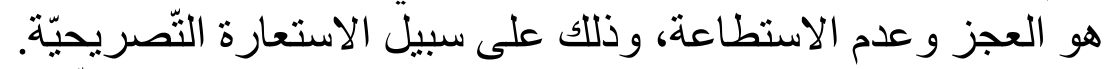

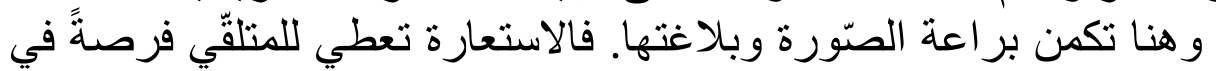

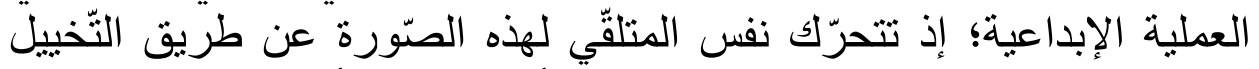

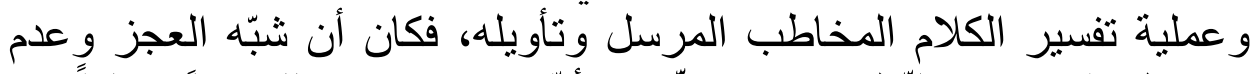

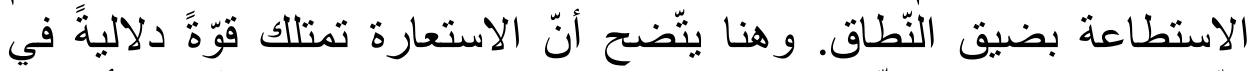

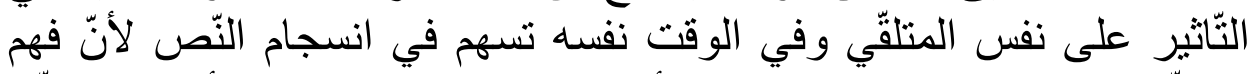
المتلقِّي للاستعارة يقوده إلى ربط الأفكار في هذه الثقامة، فإن أخفق المتلقيّي 
في فهم الاستعارة أثّر ذلك في عملية فهم النّص وقاد إلى عدم انسجامه لأنّ النّا

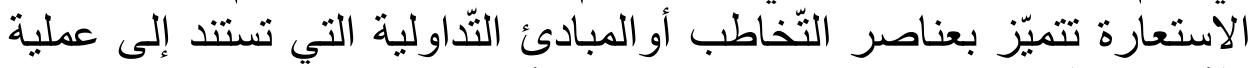

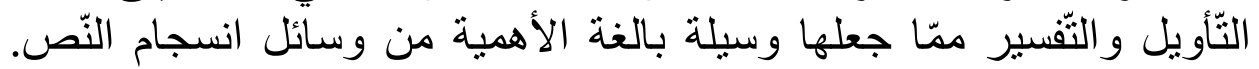
وهكذا تسهم الاستعارة في جعل النّص منسجمًا.

في هذه المقامة، يوظّف الزّمخشري الكناية كما في قوله: ال...ومَنَ غَرَسَ

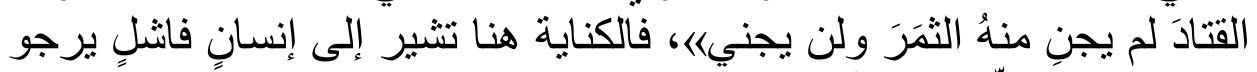

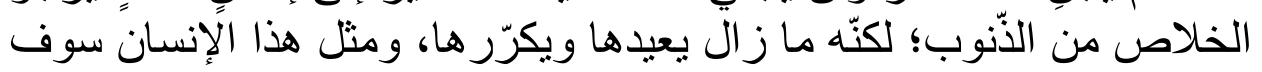

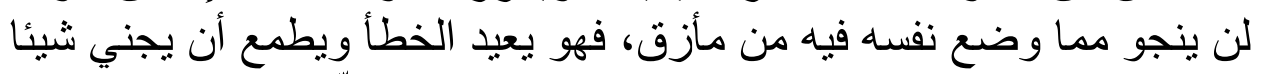

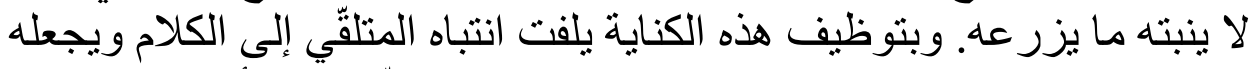

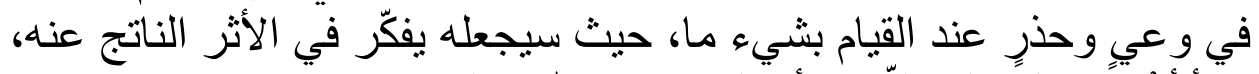

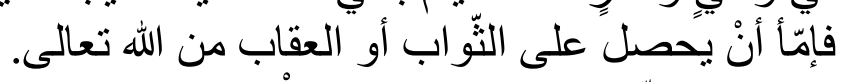

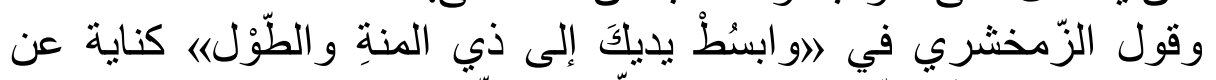

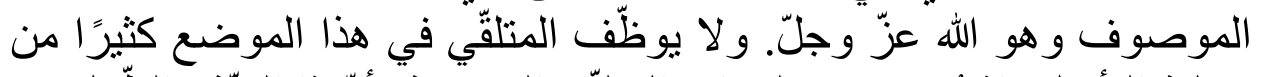

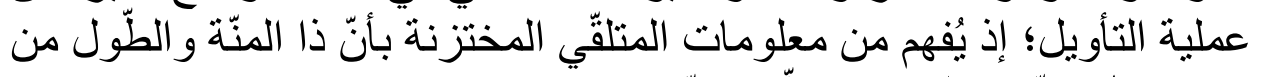

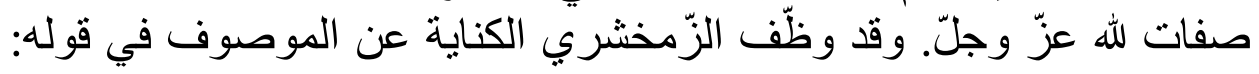

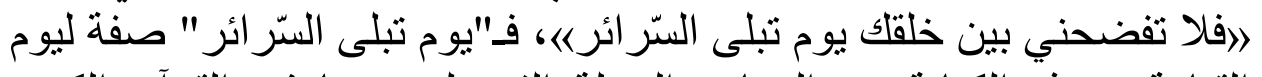

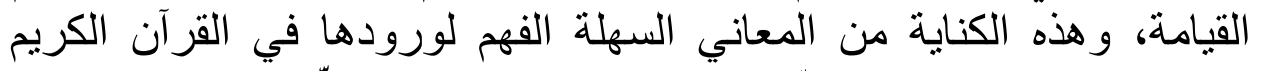

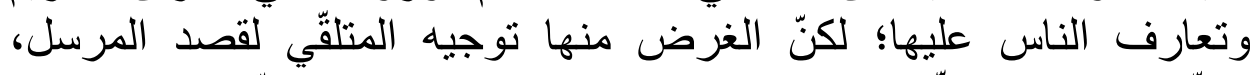

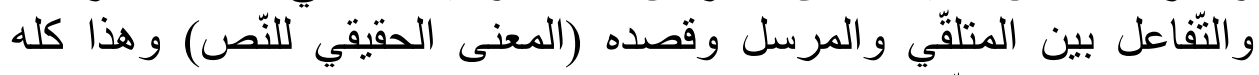
يسهم في انسجام النّص.

مقامة النّصح

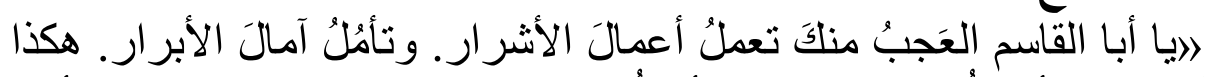

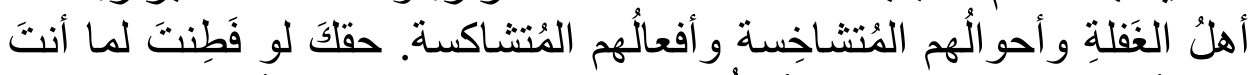

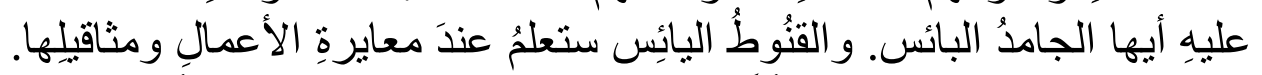

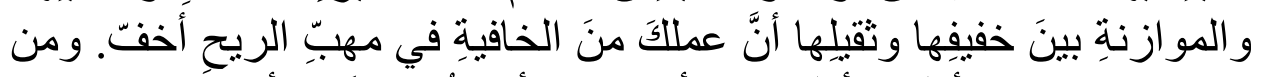

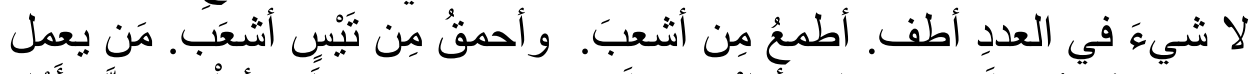

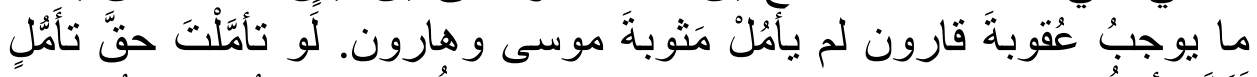

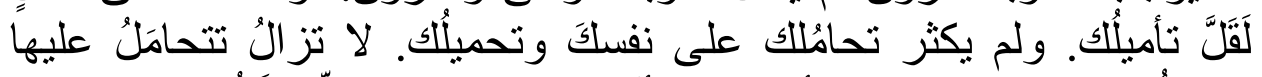

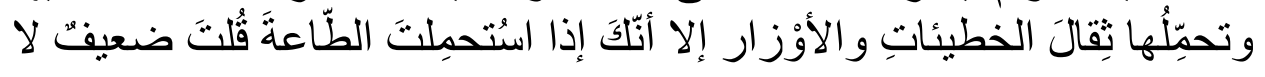




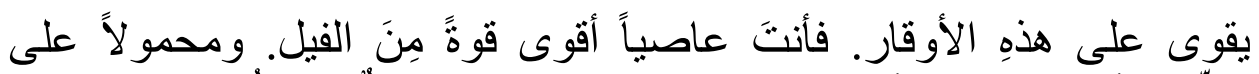

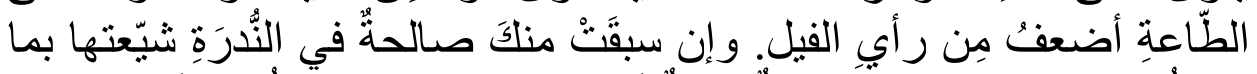

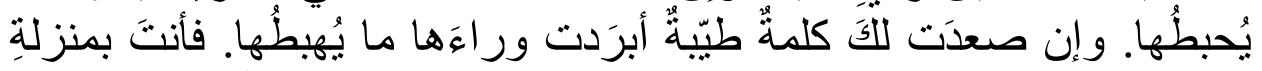

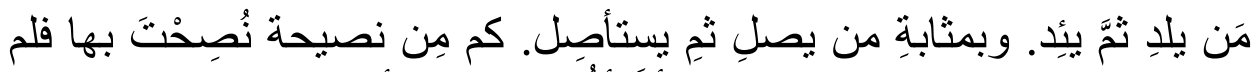

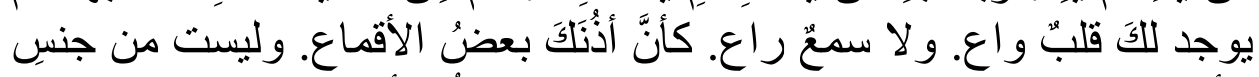

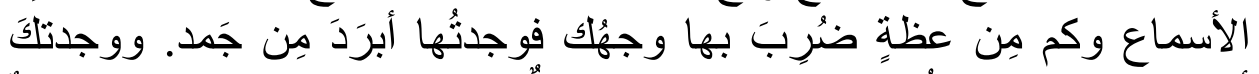

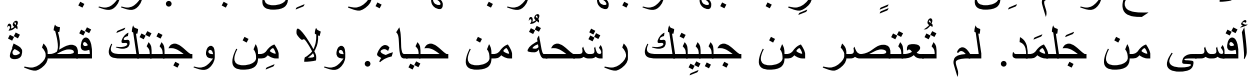

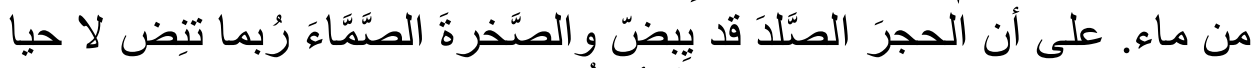

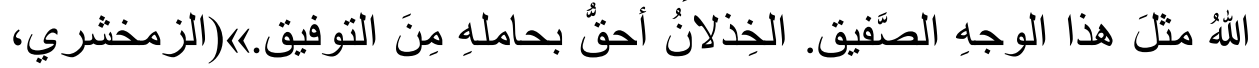

( ) V0-) V : 1914

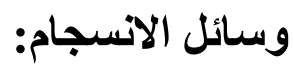

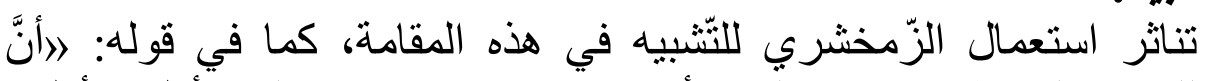

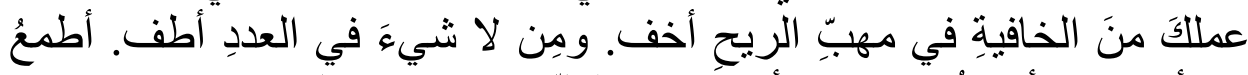

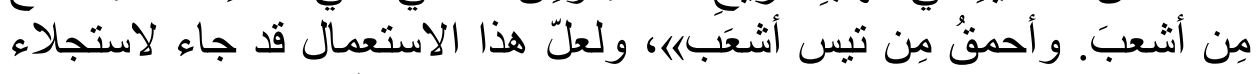

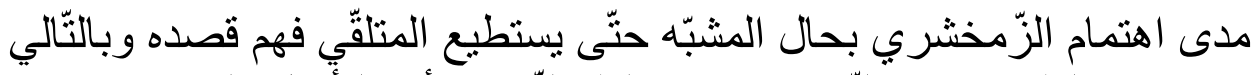

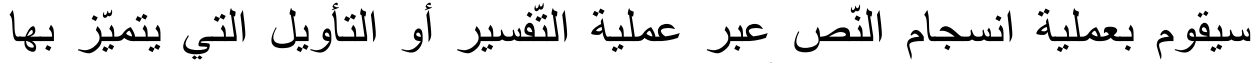

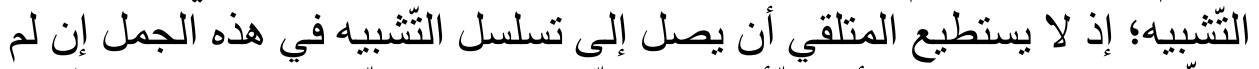

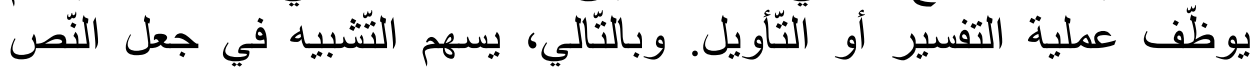
منسجمًا عبر هذه العملية.

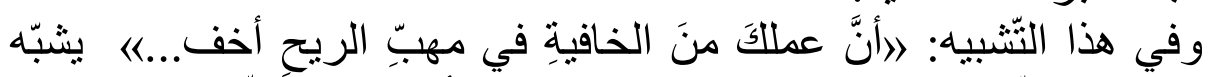

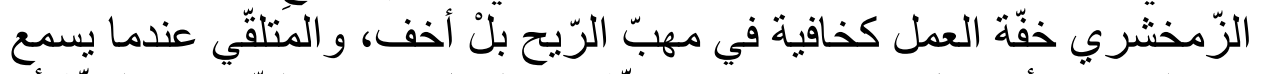

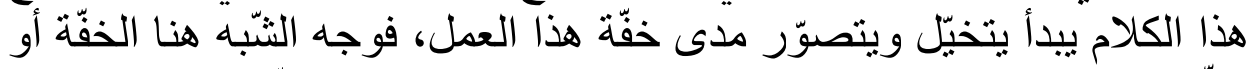

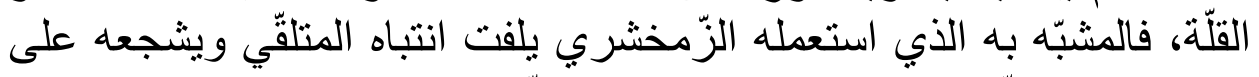

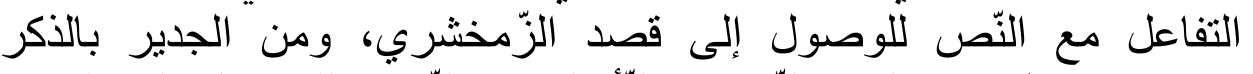

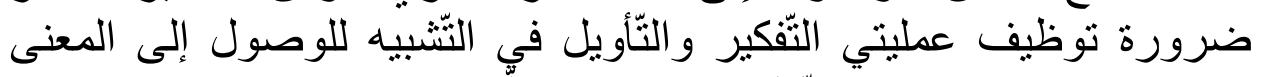

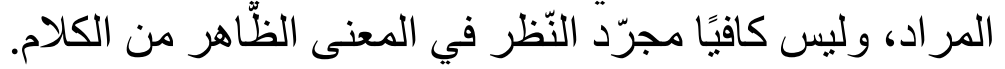

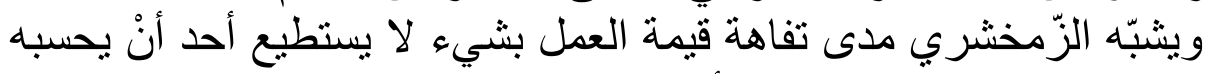

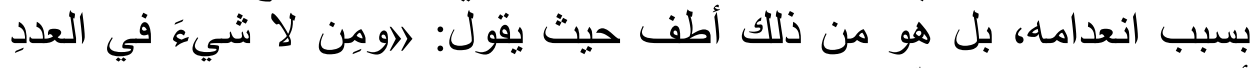

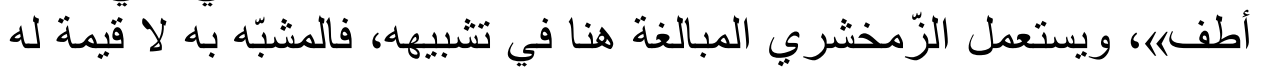


إطلاقا في الحساب، فجمع بينهما بوجه شبه هو انعدام القيمة. ومثل هذا التّشبيه

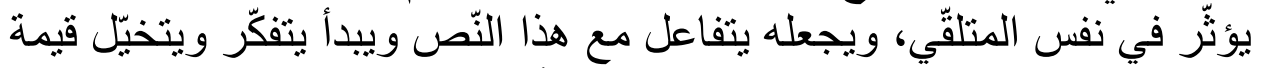

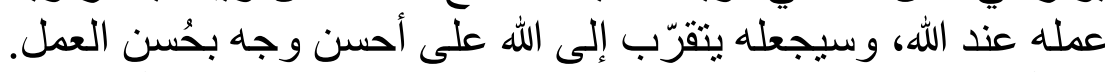

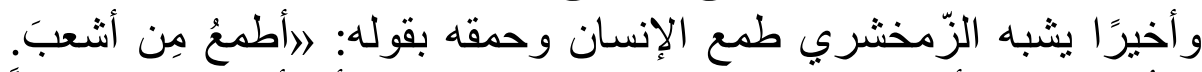

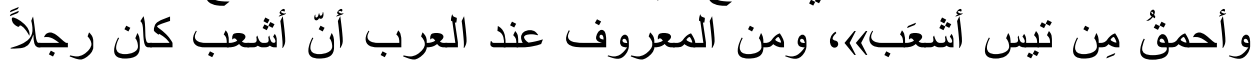

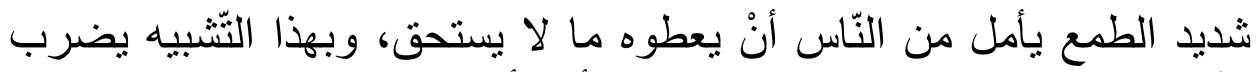

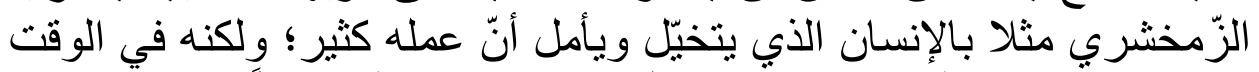

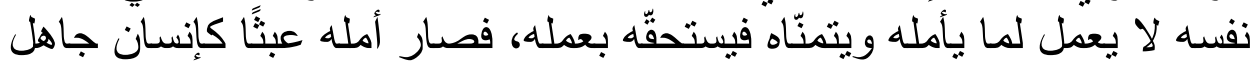

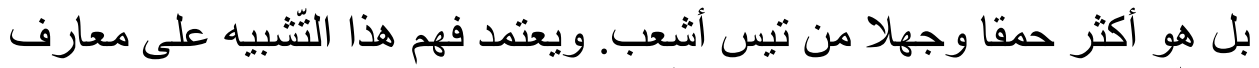

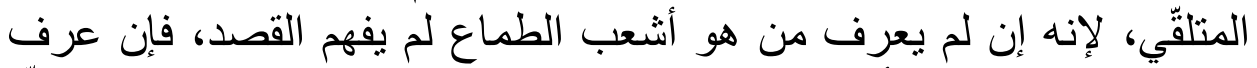

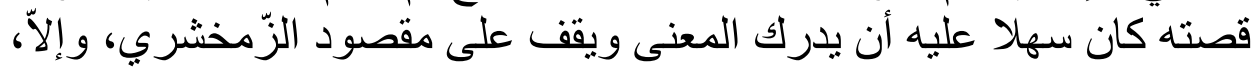

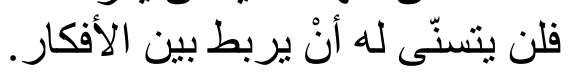

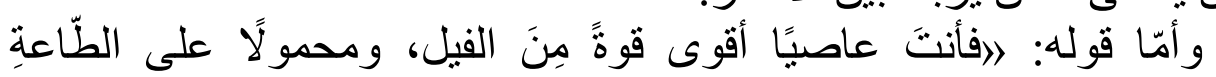

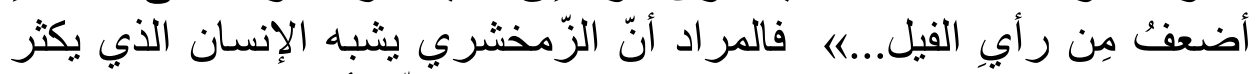

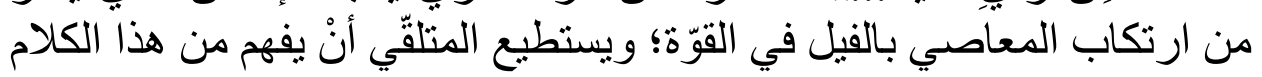

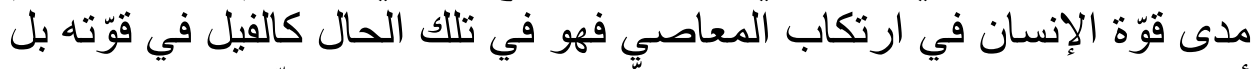

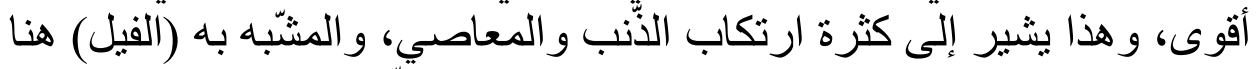

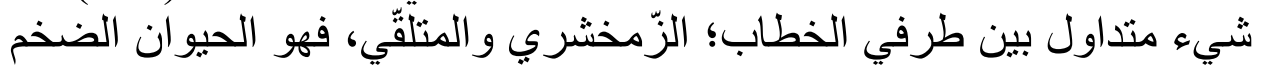

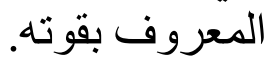

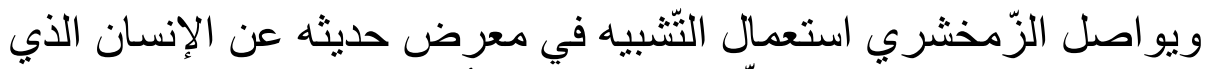

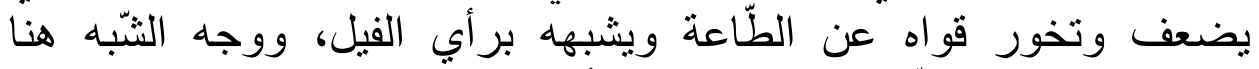

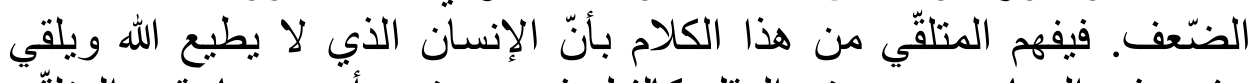

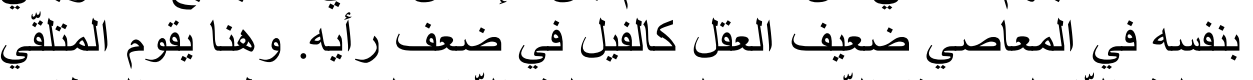

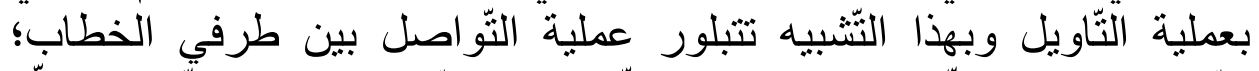

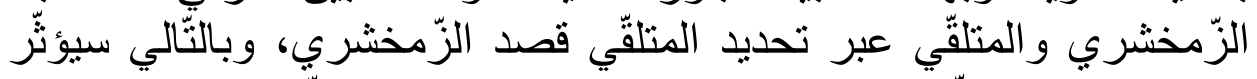

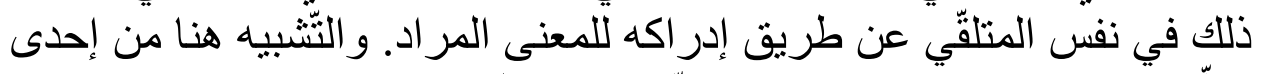

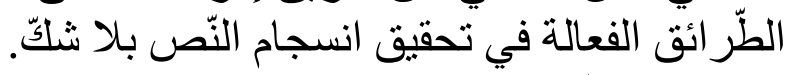

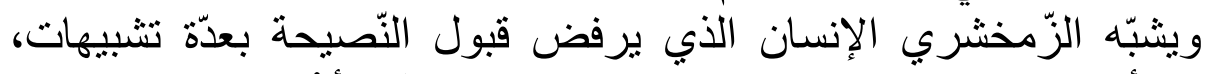

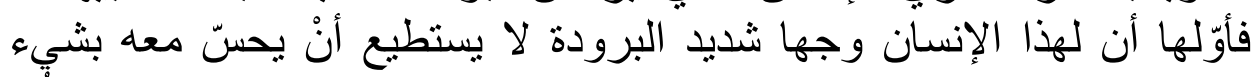

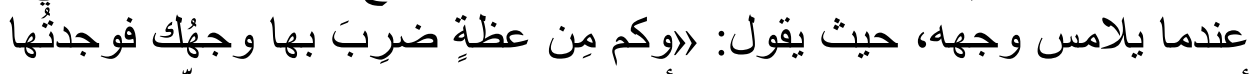

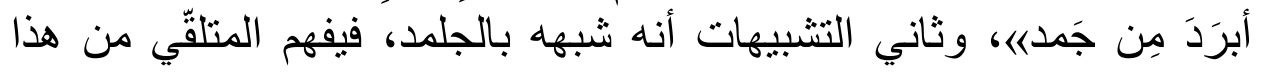


التّشبيه بأنّ الإنسان الذي لا يقبل النصيحة جامد كصخرة قاسية، لا تؤثر فيه

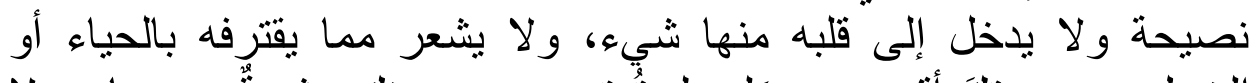

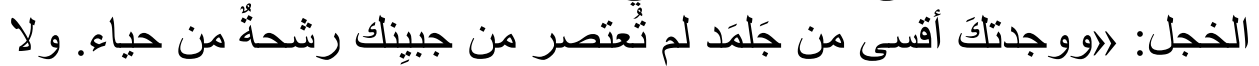

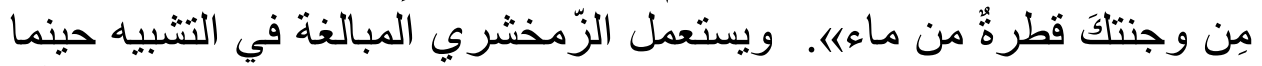

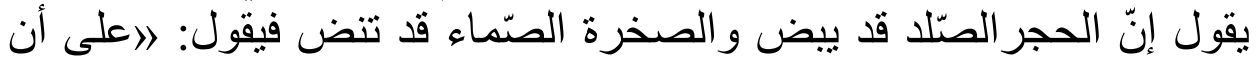

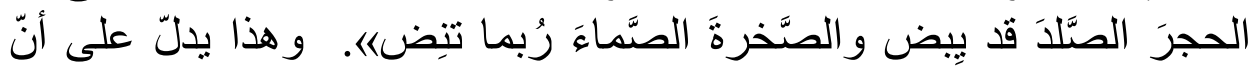

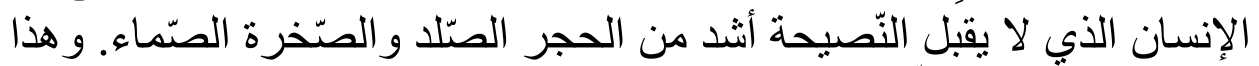

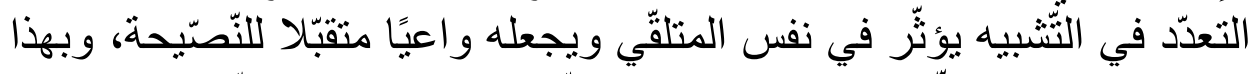

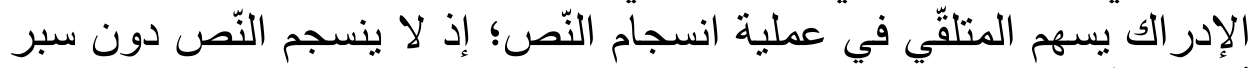

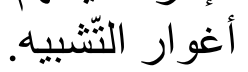

وكذلك يصوّر الزّمخشري عدم الوعي و عدم تقبّل النّصيحة بصورة شبّهّه

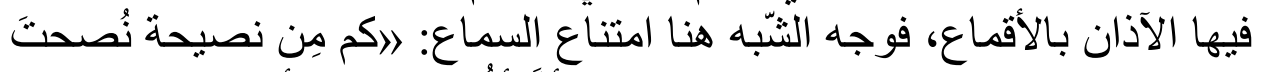

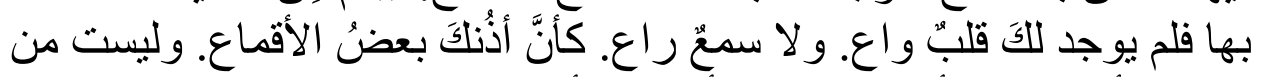

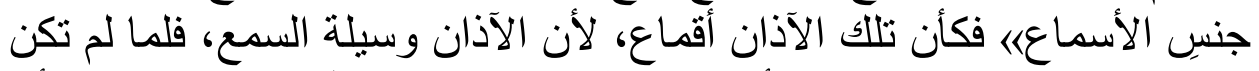

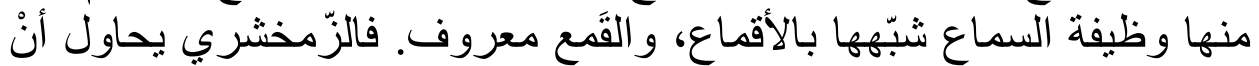

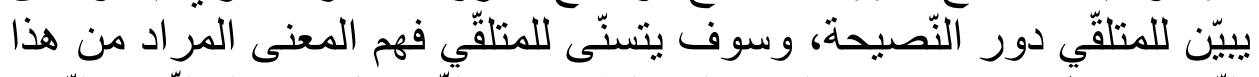

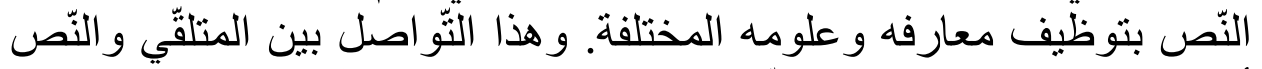

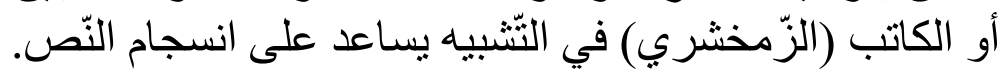

انبجست من الدّر اسة مجموعة من النّائج التي استنخلناها، و هي على النحو

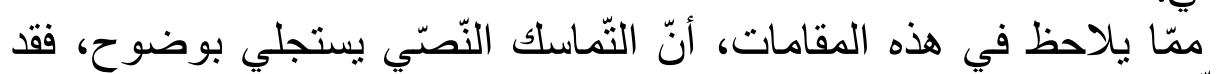

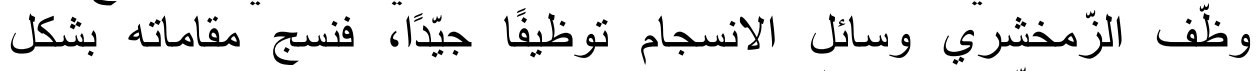

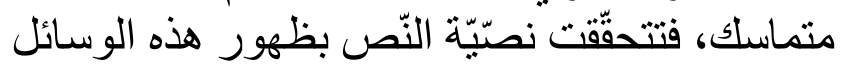

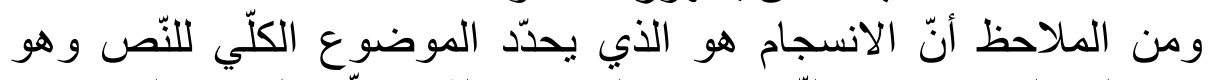

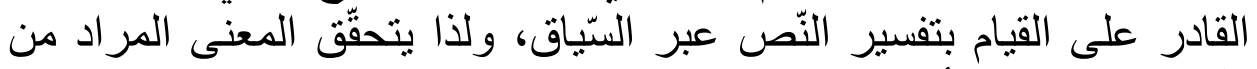

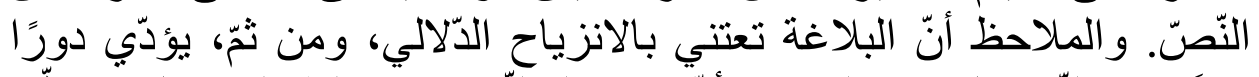

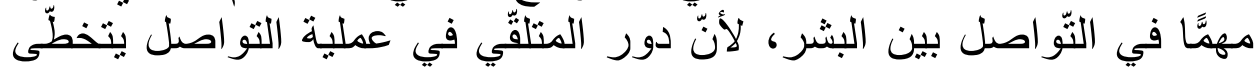
الاعتماد على الكلام المنطوق إلى اكتناه ما ور اء ذلكّ للك. 


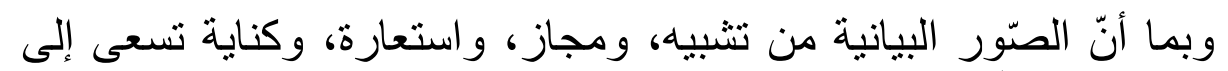

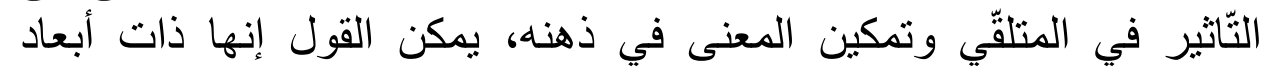
تداولية. وتمثلّت وسائل الانسجام في علم البيان عبر عملية التفكير والتأويل، وهي

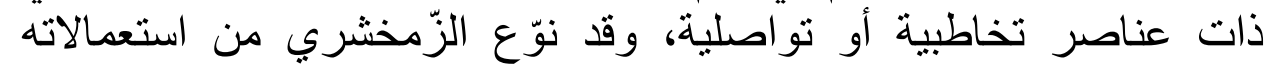

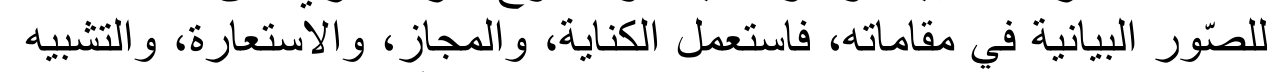

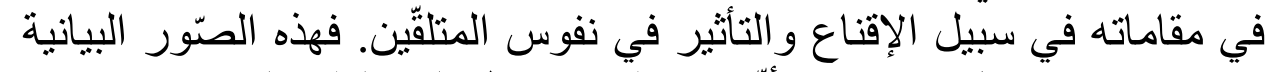

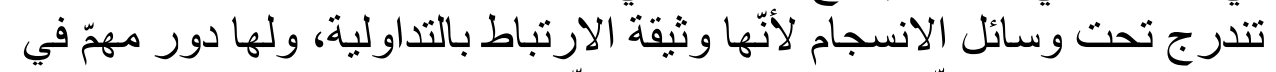

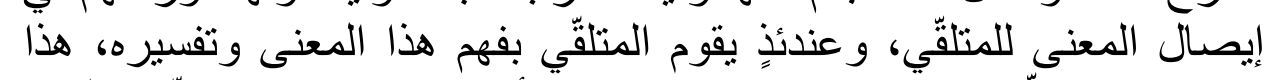

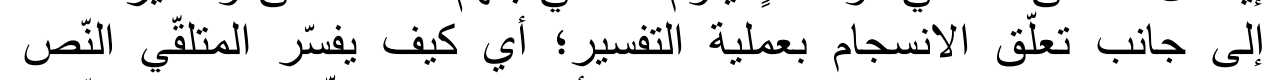

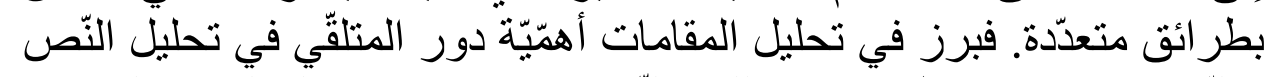

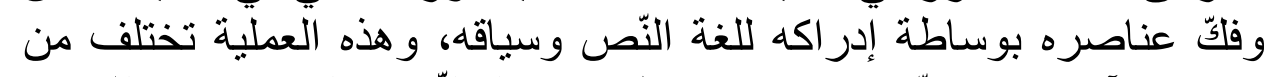

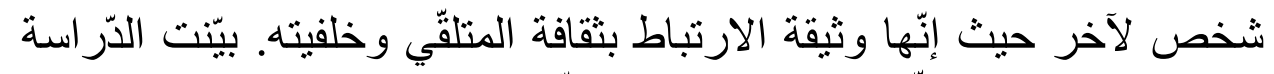

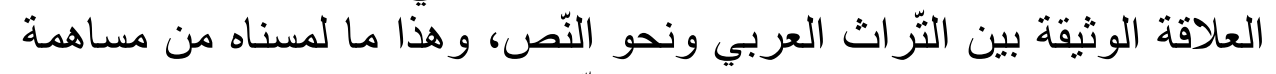
علم البيان بعدّه وسيلة من وسائل أنسجام النّص.

\section{المصادر والمراجع}

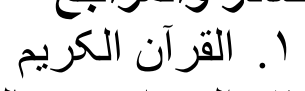

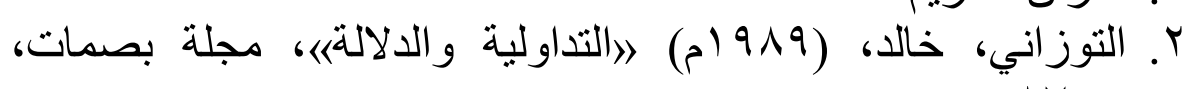

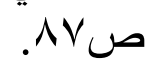

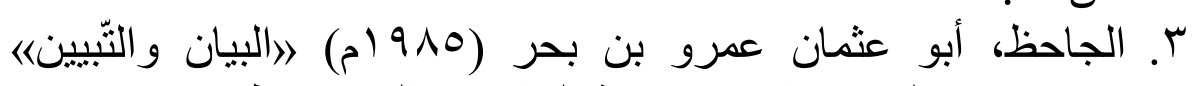

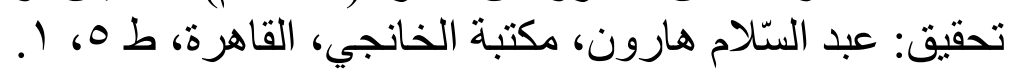

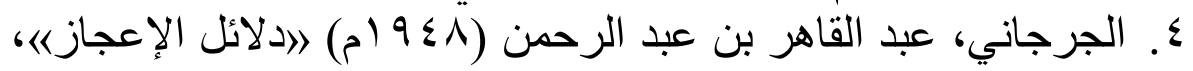

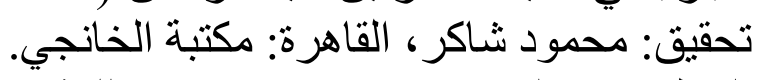

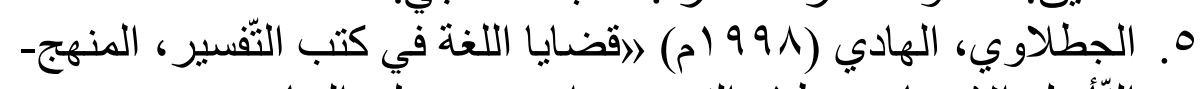

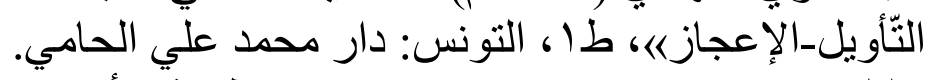

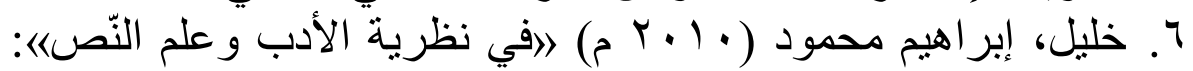

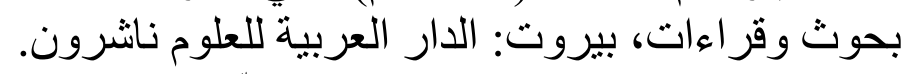

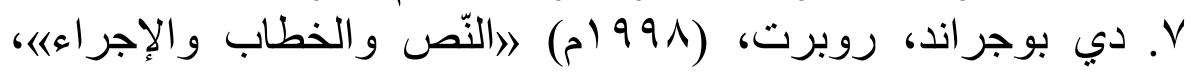
ترجمة: تمام حسان، القاهرة: عالم، عالم الكتب. 


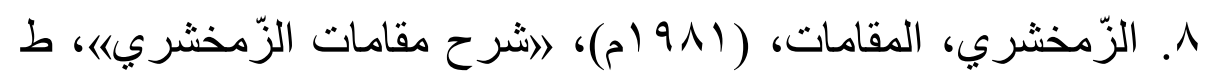
ا، تحقيق: يوسف بقاعي، بيروت، دار، دار الكتاب اللبناني.

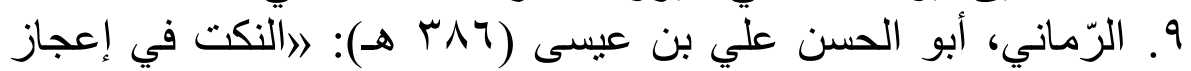

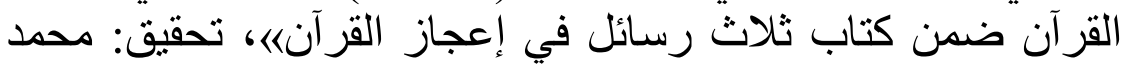

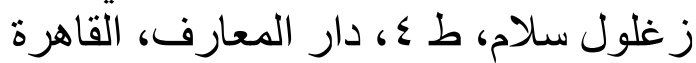

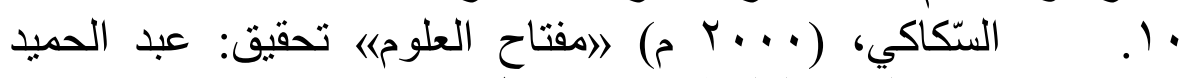

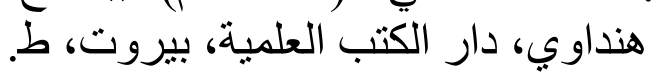

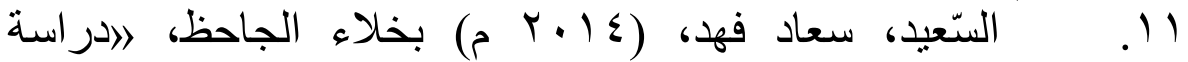

تطبيقية في علم لغة النّصها المملكة العربية السعودية: نادي أبهاء أبها

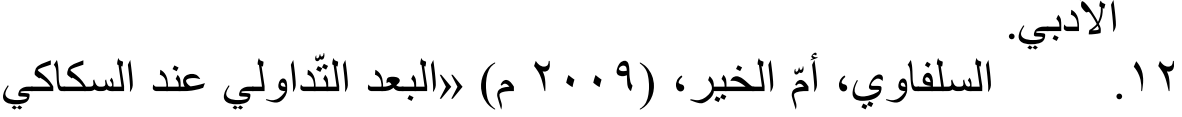

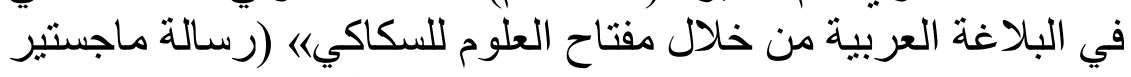

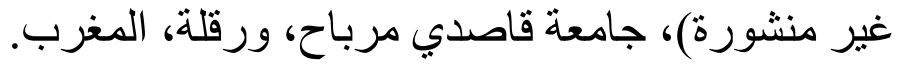

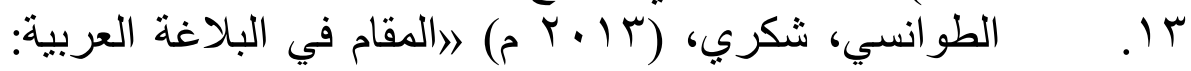

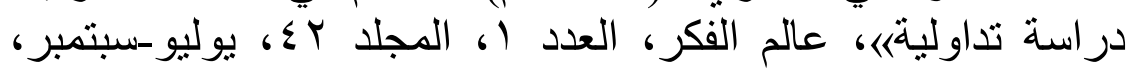

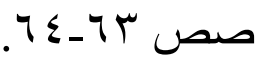

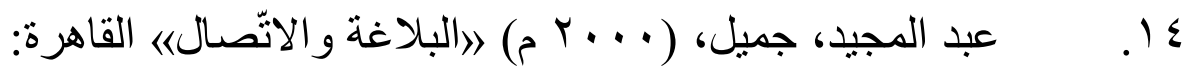

دار غريب.

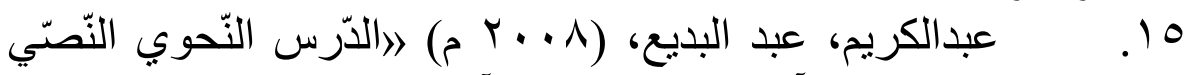

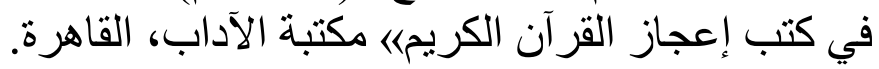

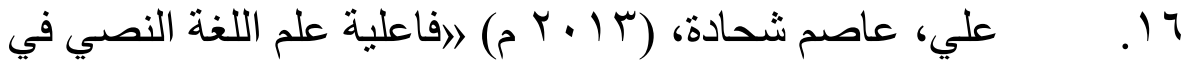
تحليل معهود للخطاب العربياء، كو الا لمبور : مطبعة الجامعة.

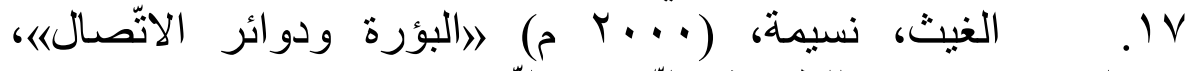

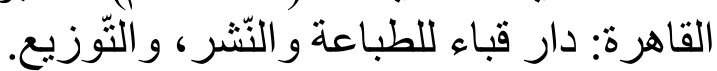

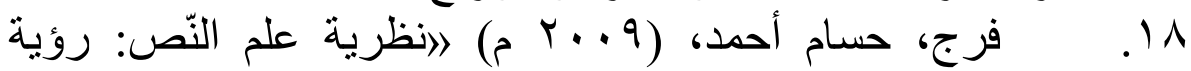

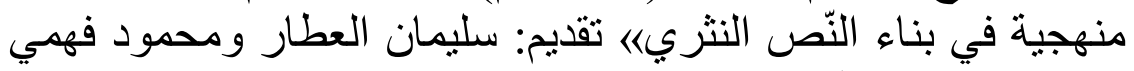
حجازي، مكتبة الآداب، القاهرة.

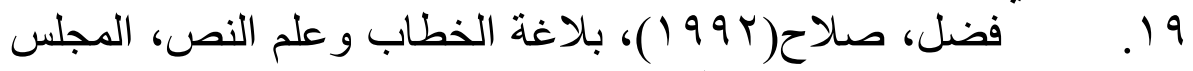
الوطني للتقافة و الفنون والآداب، الكويت. 


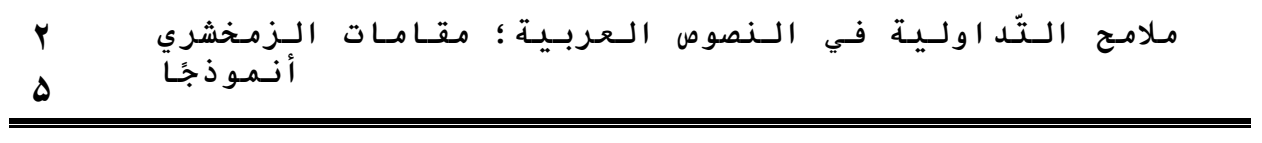

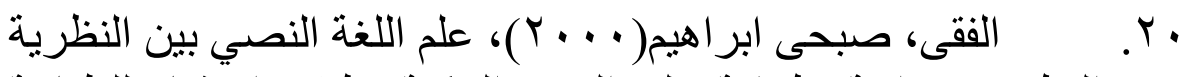

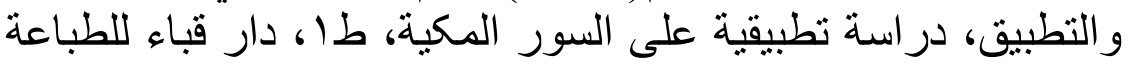

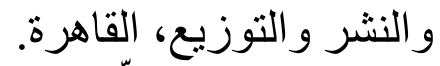

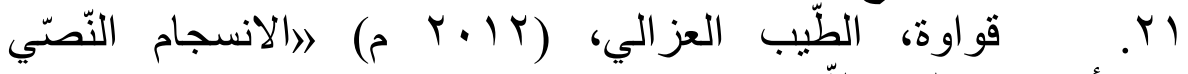

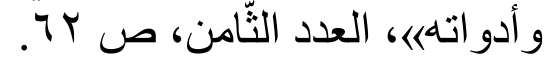

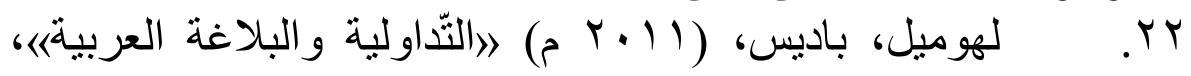

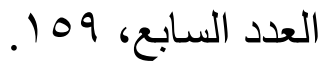

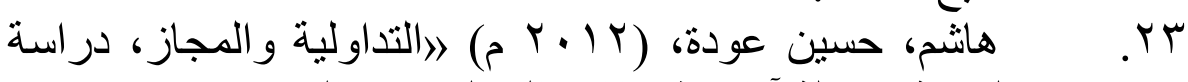

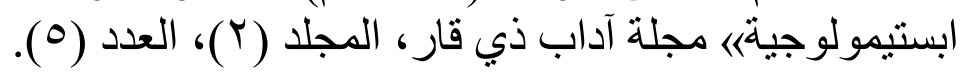




\section{References}

1. The Holy Qoran

2. Attawazoni, Khalid,(1989), "Pragmatics and Semantics", Basomat Journal.

3. Al-Jahiz, Abu Uthman Amru Bin Bahr, (1985), The Statement and Explanation. Al Khanji Publishing.

4. Al-Jorjani, Abd al-Qaher Ibn Abd al-Rahman (1948 AD) "Evidence of Miracles", edited by Mahmoud Shaker, Cairo: Al-Khanji Library.

5. A-Jatlawi, Al-Hadi, (1998), Language Issues in Book of Exegesis, Method-Interpretation-Miracles, Attunis: Muhammad Ali Al-Hami Publishing.

6. Khalil, Ibrahim Mahmud, (2010), In literature theory and textual science: research and readings, Beirut: The Arab Science House Publisher.

7. De Beaugrande, Robert, (1998), Text, Speech and Procedure. Translation: Tammam Hassan, Al Qaherah: Book World.

8. Az-Zamakhsyari, (1981), Al-Maqamat, The Explanation of Al-Maqamat Azzamakhsyari. Beirut: Lebanese Book House.

9. ARumani, AbulHassan Ali Bin Isa, (386) Jokes in Miracle of Qur'an in the book Three Letters on the Miracles of the Qur'an. Knowledge House, Cairo.

10. As Sakaki, (2000), The Key of Science. Beirut: Scientific Book House.

11. Al Saied Su'ad Fahd, (2014), Bakhla Al-Jahiz, An Applied Study in Textual Linguistics, Saudi Arabia: Abha Literary Club.

12. Al-Salfawi, Ummulkhair, (2009), The pragmatic dimension of Sakaky in Arabic rhetoric through the key of sciences by Sakaky. (unpublished Master Thesis), Al Maghrib: Qasidi Merbah University, and Ouargla

13. Attawanisi, Syukri, (2013), "Maqam in Arabic Rhetoric: A Pragmatic Study", Thought World Court Journal.

14. Abdul Majid, Jamil, (2000), Rhetoric and Communication, Al Kaherah: Strange House Publishing.

15. Abdul-Karim, Abdel-Badi", (2008 AD) "Textual grammatical lesson in the books of the Noble Qur'an inimitability" Arts Library, Cairo.

16. Ali, Asem Syahadah, (2013), The effectiveness of textual linguistics in a typical analysis of Arabic discourse. Kuala Lumpur: University Press.

17. Al Ghais, Naseemah, (2000), Focus and circles of communication, Al Kaherah: Quba House for printing, publishing, and distributing. 


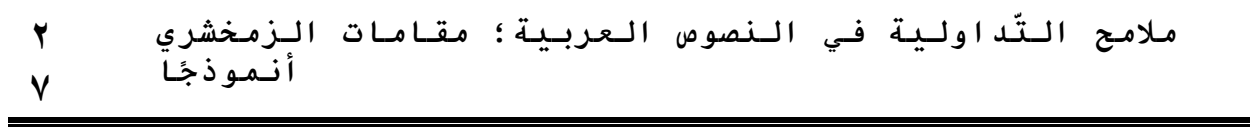

18. Farj, Hisam Ahmad, (2009), Text science theory: a systematic view of constructing the prose text. AlKaherah: Literature Library.

19. Fadl, Salah (1992), Rhetoric of Rhetoric and Textual Science, The National Council for Culture, Arts and Literature, Kuwait.

20. Al-Fiqi, Sobhi Ibrahim (2000), Textual Linguistics between Theory and Application, An Applied Study on the Meccan Surahs, First Edition, Dar Quba for Printing, Publishing and Distribution, Cairo.

21. Qawawah, Attayyib Al 'Azali, (2012), Coherence and its tools, Al Makhbar Journal.

22. Lahomel, Badis. (2011), Pragmatic and Arabic Rhetoric Vol. 7

23. Hashim, Hussein 'Audah, (2012), Pragmatics and Metaphor, an apistomology approach. Dhi Qar Literature Journal, Vol.2, no.5. 


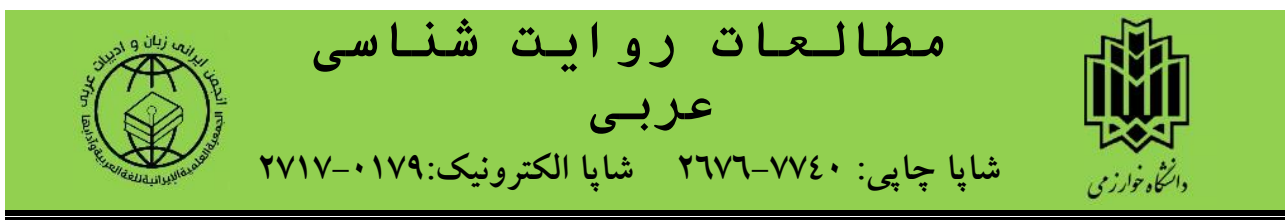

نمودهاى :راكماتيسم در متون عربى: بررسى موردى مقامات زمخشرى

hanilah@iium.edu.my

رايانامه:

نورالحنيله بنت محمد عصمت

استاد دانشكده زبان و مديريت، دانشخاه بين المللى اسلامى مالزى، مالزى، نويسنده مسوول abdulhadi@uthm.edu.my رايانامه: عبد الهادى بن عبد العزيز

mnzainiyah@iiu.edu.my يزوهشكر مركز يزوهش هاى زبان، دانشكاه تون حسين اون مالزى ئ. arinajr@iium.edu.my رايانامه:

نور زينيه نوريتا مختار

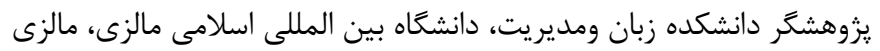
رايانامه:

آرينا بنت جوهرى يزووهشكر دانشكده زبان ومديريت، دانشكاه بين المللى اسلامى مالزى، مالزى اليامه

از آنجايى كه صور بيانى از جمله تشبيه، مجاز، استعاره وكنايه به دنبال تأثير كذارى بر مخاطب وجا انداختن معنا در

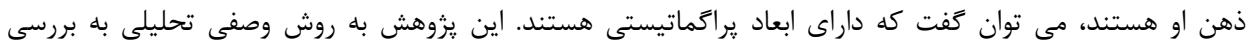

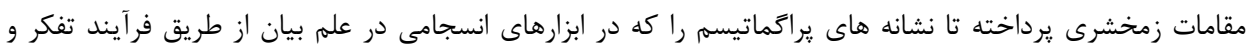

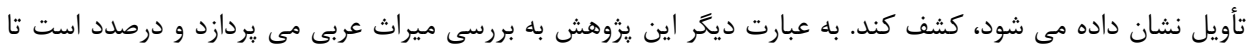

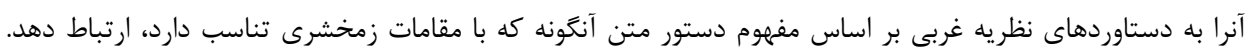

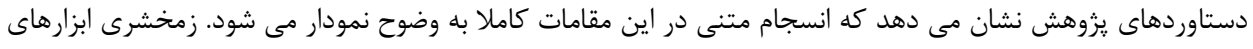

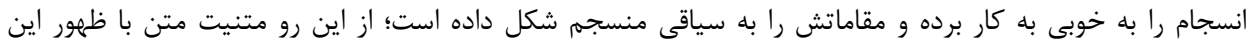

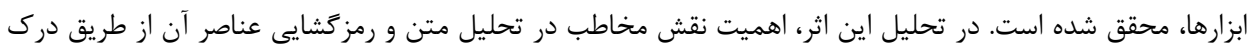

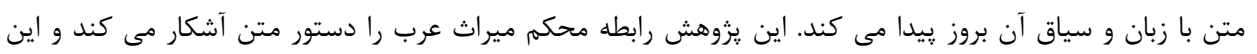

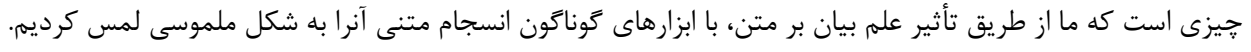

وازگًان كليدى: يزوهش هاى روايت شناسى عربى، دستور زبان متن، انسجام متنى، يراگماتيسم، علم بيان، مقامات

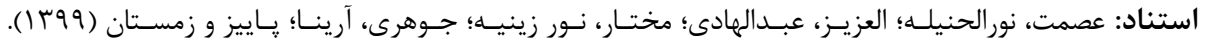

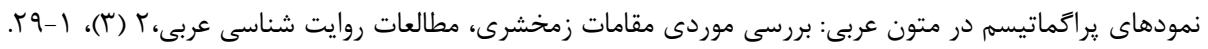

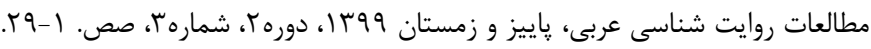

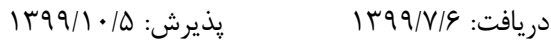




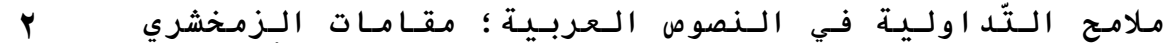 9}

(C) دانشكده ادبيات وعلوم انسانى دانشكاه خوارزمى وانجمن ايرانى زبان وادبيات عربى 